rev.relac.int.estrateg.segur.5(1):161-191,2010

\title{
NACIÓN Y HEROÍSMO EN COLOMBIA - 1910-1962
}

\author{
Rafat Ghotme*
}

\section{RESUMEN}

En este artículo se analiza el mito de Santander en los manuales de historia patria, en la primera mitad del siglo XX, como el estereotipo de la tradición, la identidad nacional y el arquetipo de un hombre particular, con las cualidades individuales y colectivas propias del alma nacional. Esta tarea sería implementada por la Academia Colombiana de Historia, que junto con el Gobierno nacional durante el periodo 1910-1962 se dio a la tarea de masificarlo y darle una vida autónoma y perdurable.

Palabras clave: Mito, nacionalismo, identidad nacional, héroes, antihéroes, academia colombiana de historia, manuales de historia Patria, General Santander.

\section{ABSTRACT}

This article examines the myth of Santander in the history books of the first half of the twentieth century, as the stereotype of

\footnotetext{
* Docente e Investigador de la Universidad Militar Nueva Granada, Facultad de Relaciones Internacionales, Estrategia y Seguridad. elturcal@hotmail.com
} 
tradition, national identity and the archetype of a special man, with the individual and collective qualities proper of the national soul. This task would be implemented by the Colombian Academy of History, which along with the national government, during the period 1910-1962 undertook the task of normalize and give him an autonomous and enduring life.

Key words: Myth, Nationalism, National Identity, Heroes, Anti heroes, Colombian Academy of History, History books, General Santander.

\section{INTRODUCCIÓN}

Como después de la Guerra de los Mil Días el país se encontraba en una penosa ruina fiscal, se concibió en la educación el modelo nacional del progreso a fin de evitar nuevas confrontaciones y elevar el nivel de la riqueza, el espíritu y el carácter nacional por la senda de una civilización moderna y cristiana.

Después de un siglo plagado de guerras civiles, una supuesta fractura de la identidad colectiva nacional y un marcado desinterés por la historia, tal como lo denunciara la Academia Colombiana de Historia en sus informes anuales, los intelectuales - centenaristas y republicanos- y los dos partidos políticos enrumbaron el proyecto nacionalista de vincular la Nación con el Estado y tratar de compaginar una ideología cívica de elites con la base popular. Al pueblo colombiano y a los líderes del siglo XIX se les caracterizaba por tener un desenfrenado ímpetu belicoso, guerreristalegalista, apasionado y encarnizadamente banderizo. A los intelectuales nacionalistas de inicios del siglo XX no les bastaba con censurar la tremenda atracción de los hombres del XIX por defender las instituciones y las leyes por medio de las armas, sino que además les deploraban su desconocimiento de los hechos del pasado, los grandes hombres, los verdaderos patriotas y la indiferencia por la historia. A la historia, por lo demás, le atribuyeron el papel científico y moral de atemperar las disputas que presentaba la jurisprudencia y los encomiados debates románticoliberales del siglo XIX1.

A pesar de los distintos modelos políticos de construir nación por parte de los dos partidos, fue la Academia Colombiana de Historia, entonces, la que trató de imponer un modelo ideal de patriotismo; contribuyó, además, con la función de incorporar referentes históricos, culturales y cívicos comunes por medio de los hechos y figuraciones míticas del pasado. Además de cultivar o mitificar la vida de los grandes hombres, los intelectuales nacionalistas, políticos e historiadores de la Academia Colombiana de Historia supusieron en la educación la principal forma como se

\footnotetext{
${ }^{1}$ Cfr. Ramón Correa, «Bocetos Biográficos», Boletín de Historia y Antigüedades, VI 61 (julio de 1909): 11; Raimundo Rivas, «Duda Histórica», Boletín de Historia y Antigüedades, VI.64 (septiembre de 1910): 243 y ss.; Pedro María Ibáñez, "Informe anual del Secretario de la Academia», Boletín de Historia y Antigüedades, VI.65 (octubre de 1910): $275-276$.
} 
estructuraría la convicción de pertenencia a la Patria. Revelado el mito del patriota, el estereotipo de la tradición y la identidad nacional, por un lado, y el arquetipo de un hombre particular, con las cualidades individuales y colectivas propias del alma nacional, por el otro, vendría la tarea de masificarlo y darle una vida autónoma y perdurable: esta tarea recayó en la enseñanza de la historia, los manuales o textos de historia patria y las fiestas cívicas del 20 de julio o el 7 de agosto en medio del populacho concentrado alrededor de los fuegos artificiales y las festividades folclóricas ${ }^{2}$. Al general Santander, por lo demás, se le consagra gran parte de esa revelación mítico-patriótica en medio de una pléyade de héroes y antihéroes donde él mismo ocupa un lugar destacado en la construcción compleja de la nacionalidad ${ }^{3}$.

\section{MITO E HISTORIA}

En la mitificación de Santander en los manuales de historia patria ¿qué representación, psicológica e histórica cabe darle al «mito» en la construcción de la identidad? En una percepción psíquica del mito el ser torna una estructura sintética del imaginario, representada, como diría Durand, en las imágenes arquetípicas o simbólicas de su salvación y heroísmo trascendental ${ }^{4}$. En el esquema

2 Cfr. "Informes Anuales de los Secretarios de la Academia, 1902-1952», compiladas por Roberto Velandia, Academia Colombiana de Historia, Bogotá, 1952. Además de los decretos 491 de 1904, 1763 de 1923 y 45 de 1962, que reglamentaron la enseñanza de la Historia Patria bajo los parámetros de la "pedagogía nacionalista», la Academia, por medio de los decretos 2388 de 1948 y 3408 de 1948, quedó "encargada de la suprema vigilancia de los programas, de los textos y de todos los elementos vinculados a la enseñanza de la Historia Nacional», en "Información del Secretario sobre la Cátedra de Historia», Boletín de Historia y Antigüedades, XXXVI (1949): 45; y «Enseñanza de la Historia Patria. Normas, estímulos, sanciones» (Bogotá: Ministerio de Educación Nacional, 1949).

${ }^{3}$ En este artículo se siguen los conceptos vistos en mi artículo anterior sobre santanderismo y antisantanderismo, en el que se dejó entrever que en medio del debate sobre el General Santander como padre fundador de la nación, existen posiciones historiográficas, políticas y partidaristas divergentes. Con la conexión entre estos rasgos de la identidad nacional y, por ende, de los factores históricos inmersos en las situaciones mitológicas, este debate encarnizado que raya con el odio, el amor y los personalismos de los autores en torno a Santander, es extremadamente útil para este estudio donde los textos de historia patria hacen una valoración mítica del pasado, obra y figuración del General, transfigurando ese debate en nombre de una nacionalidad única. Santander encarna entonces la idea del «héroe nacional» en los manuales. Véase mi artículo "Santanderismo, antisantaderismo y la Academia Colombiana de Historia: la operación histórica en el proceso de construcción de nación en Colombia, 1910-1970», Anuario Colombiano de Historia Social y de la Cultura, 34 (2007).

${ }^{4}$ Sobre el trascendentalismo (superar el descontento y desafiar el destino impuesto por los dioses); el ascencionismo (héroe solar o lunar luchando de manera "vertical», hacia arriba, viva "representación» del héroe ascendiendo y pisoteando al adversario en las "tinieblas o contra el abismo»); las imágenes arquetípicas y simbólicas, que más allá del héroe colorea la función de las armas, la flecha y la espada, que son «alzadas y erguidas", representan la verticalidad, trascendencia y virilidad del hombre en determinada época histórica, en Gilbert Durand, Las estructuras antropológicas de lo imaginario. Introducción a la arquetipología general, (Madrid:Taurus, 1981), 151-153, 338-339. 
metodológico de Durand, representado en los Regímenes Diurno y Nocturno del imaginario, existe una relación necesaria entre el semantismo arquetípico y simbólico, por un lado, y el relato mítico, dramático e histórico, por otro lado. Esta relación no se bastaría a sí misma si no incorpora los elementos del Régimen Diurno, esto es, la hazaña del héroe solar apolíneo ${ }^{5}$, y los elementos del Régimen Nocturno, basado en la obediencia estricta de los héroes a un destino escrito, a unos padres-dioses. Los dos Regímenes, dice Durand, por sí solos, serían pura representación aislada de la función mítica; para que el mito sea tal cosa, requiere, además de su dinámica intrínseca semántica, «un dinamismo extrínseco» que, unidos los dos, forman el «relato» ${ }^{6}$. Esto indica dos cosas. Por una parte, que el mito es «el relato que legitima tal o cual fe religiosa o mágica», una leyenda y sus indicaciones explicativas -incluyendo además al cuento popular o la novelería-. Por otra parte, «el mito no es exclusivamente el hilo del relato, sino también el sentido simbólico de los términos» ${ }^{7}$. Así las cosas, la comprensión del mito, esto es, la mitología, queda circunscrita a una historia además de los dioses paganos antiguos y de su acción sobre los hombres y los semidioses- de héroes y antihéroes.

Pero ¿quiere decir esto que queda supeditado el mito simplemente a una narración fantasiosa de héroes que no va más allá de las percepciones del público receptor y de la historia misma? Según Roger Caillois, el mito es una proyección de la frustración psíquica del individuo, que choca con la sociedad y la civilización; de esta forma una situación mítica refleja los conflictos cotidianos del ser (la humillación, por ejemplo, de Edipo), que tratan de ser resueltos con acciones que van más allá de su alcance ${ }^{8}$. (Es posible que el hombre rara vez tenga conciencia de esos conflictos psíquicos, debido a que estos sugieren, según Caillois, que son el resultado de la estructura social o "la consecuencia de la obligación que hace pesar sobre sus deseos elementales». Es posible también que estas presiones obedezcan a impulsos biológicos o individuales del ser, que en la concepción freudiana aduce una perfecta libertad de acción humana sobre la sociedad. No nos interesa discutir este aspecto aquí). Por esa razón, el individuo -y las sociedades- transponen su frustración y sus humillaciones ante la figura sobrehumana de su héroe predilecto que, entre otras cosas, es capaz de asumir toda la responsabilidad de la «liberación», incluso si tiene que soportar toda la carga de la humillación y sobreponerse a los tabúes de la sociedad. Historia y mito -este último como concepto moderno-, hacen referencia a la aprehensión de un pasado en función de referentes conceptuales y simbólicos en donde el ser se encuentra a sí mismo como un individuo dramatizado y en el que aparecen diversas situaciones heroicas que lo determinan y realizan. Un aspecto crítico de la modernidad política, desde Nietzsche, introduce esta concepción psíquico-histórica del mito como el acto en que conscientemente el nacimiento de un héroe legitima en el poder «la dignidad de una vieja verdad», que tiene «la meta política de un orden futuro que debe ser creído por todos»⿳.

\footnotetext{
${ }^{5}$ Matar con la espada y liberar la luz, el sol de las temidas tinieblas.

${ }^{6}$ Durand 338.

7 Durand. 339.

${ }^{8}$ Roger Caillois, «El mito y el hombre», traducción de Ricardo Baeza, Ediciones Sur, Buenos Aires, 1939, p. 29.

${ }^{9}$ Hans-Georg Gadamer, Mito y razón (Barcelona: Ediciones Paidós Ibérica, 1997).
} 
Se abordará, por tanto, el análisis de la mitologización de Santander en los textos de historia patria, circunscribiendo sus apariciones litografiadas y textuales a la legitimación de una nueva fe política -el nacionalismo-, como consecuencia de la realidad histórica colombiana de principios del siglo XX ${ }^{10}$.

\section{SANTANDER EN LOS TEXTOS ESCOLARES DE HISTORIA PATRIA}

En los textos escolares de historia patria el general Santander aparece como el Hombre de las Leyes y el Organizador de la Victoria. Ambos términos indican que el general es un héroe primigenio de la Independencia, pues sin sus actos la libertad y la consumación del nuevo régimen republicano, además de la ejecución de la guerra contra España, no se hubieran perpetuado. Aparece junto a Bolívar ceñido de laureles; éste como el Padre de la Patria, y Santander como el fundador de la República y Padre de la Nación. En algún pasaje incluso supera las fronteras nacionales: es el héroe de la administración americana en medio del $\operatorname{caos}^{11}$. Durante la narración heroica la obra de Santander aparece dividida en dos etapas. La primera de ellas va de 1810 a 1828, es decir, desde el comienzo de la Independencia hasta cuando Santander es expulsado del territorio por su supuesta conspiración contra Bolívar. En este periodo Santander participa en las batallas independentistas decisivas, en el nacimiento y formación de la República, su organización en medio del caos y la disolución de la Gran Colombia. Esta primera etapa también cubre su primer gobierno vicepresidencial, encargado del poder ejecutivo, como hombre de ímpetu, administrador y civilista. Es un militar joven, audaz, intrépido, hábil y con don de mando.

La segunda etapa va de 1832 a 1840, cuando Santander vuelve del exilio como primer magistrado de la república, hombre de primer orden en la consolidación de la nacionalidad y la última etapa

\footnotetext{
${ }^{10}$ La escogencia de este periodo se basa en que a partir de 1910 comienza en Colombia una política de convivencia entre los partidos liberal y conservador, con sus diferentes intermitencias, que no afectan directamente el nacionalismo implícito en los textos y la enseñanza de la historia. También por ser el año en que aparece el primer texto moderno de historia con imágenes litografiadas (Henao y Arrubla). Este periodo comprende también la reforma de ley que en 1927 hace de la instrucción primaria libre, obligatoria y gratuita, incluyendo naturalmente las dos clases "obligadas» de religión e historia, como pilares del orden cultural colombiano; sigue por el momento cumbre del nacionalismo cultural cuando se estipuló que la enseñanza de la historia, desde 1930, fijaría sendas prohibiciones a las escuelas para que los profesores extranjeros no regentaran la asignatura; continúa en 1948, después de la muerte de Gaitán, cuando se intensifica fuertemente la enseñanza de la historia, hasta llegar a la reforma educativa de 1962, donde la enseñanza de la historia muestra una línea descendente que se refleja en la reducción de horarios y la supresión de su enseñanza en varios grados del bachillerato, y desembocó en la práctica desaparición de la enseñanza de la Historia Patria -por una estructural, económica y social- en la reforma educativa de inicios de la década de 1980, que aún sigue siendo lamentada por los más acendrados defensores academicistas que abogan por su retorno inmediato. Supra, nota 2.

${ }^{11}$ José María Arboleda Llorente, Historia de Colombia, Enseñanza Secundaria y Primaria Superior, (FTD, colección Champagnat, 1939) 121.
} 
de su vida como congresista. Es mostrado como un hombre maduro o viejo, patriarca, decadente, enfermo y católico arrepentido, hasta llegar a su muerte y el legado de su semblanza para la posteridad. Al través de estas dos etapas se pueden palpar varios cambios en la personalidad del general, que corren aparejados con el hilo evolutivo de la epopeya que arranca en 1810 y comienza a oscurecerse con la muerte del Libertador en 1830 y se apaga definitivamente con la muerte de Santander en $1840^{12}$.

Aunque el general Santander está mucho menos presente en la fase 1810-1818, es a partir de 1819, con las batallas definitivas de la Independencia, en que nuestro personaje adquiere un rumbo definitivo hacia la inmortalidad. La escogencia del año 1840 como el final de la fase heroica fue basada en un aspecto crucial, la muerte del general como el hito final del areópago heroico. Es como si con la muerte del general el encanto demiúrgico surgido en 1810 llegara al final, y la narración sublime de batallas y fábulas queda en aquel pasado que ya nunca jamás volverá.

La forma como sus virtudes y yerros se envuelven con el hálito mágico de la historia, el mito y la nacionalidad se desglosarán así:

1. Santander militar y civilista.

2. Imágenes litografiadas del general Santander.

3. Enemistad con Bolívar y origen del santanderismo. Santander padre de la nación.

\section{SANTANDER MILITAR}

Santander aparece en escena en los textos en 1810, cuando estalla el movimiento revolucionario, siendo un estudiante de diez y ocho años. Pasa a alistarse como sargento abanderado del Batallón de Guardias Nacionales y al instante sucede su primer actitud deplorable por los autores: su conversión al federalismo y, por ende, la traición a Nariño, jefe de gobierno de la Provincia de Cundinamarca $^{13}$. Los autores de los manuales juzgan a Santander sutilmente: lo cierto es que Santander fue hecho prisionero en la Guerra Civil de 1813 por las tropas centralistas y puesto en libertad «con exquisita benevolencia» del vencedor ${ }^{14}$. Aunque no citan expresamente la actitud de

\footnotetext{
${ }^{12}$ Las imágenes del «cuerpo» y el ambiente físico cumplen un papel fundamental para completar el análisis del mito de Santander. Véase Infra, Conclusiones.

${ }^{13}$ Rafael Granados, Historia de Colombia La Independencia y la República, adoptado al programa oficial de sexto año, tercera edición, (Medellín: Bedout, 1959) 89-90, 98; Julio César García, Curso Superior de Historia de Colombia, de conformidad con los programas oficiales vigentes sobre la materia para cuarto año de enseñanza media, 4to. año (Bogotá: Editorial Voluntad, 1971, 10ạ edición): 127. En el texto de Henao y Arrubla, el general Santander sólo aparece hasta la campaña de 1819, en Jesús María Henao y Gerardo Arrubla, Compendio de la Historia de Colombia; para la enseñanza en las Escuelas Primarias de la República, (Bogotá: Librería colombiana Camacho Roldán \& Cía., 1930, 13a edición): 138-139.
}

${ }^{14}$ Granados 103; García 127. 
cobardía y traición de Santander, en varios textos se insinúa de una manera sutil que buena parte de los descalabros independentistas se debían al carácter de insubordinación de los granadinos, su impericia militar y el espíritu de fuga. Pero esta insinuación tiene una lógica propia de las situaciones mitológicas: pasar de la humillación y la derrota estrepitosa a la luz y la esperanza, el resurgir con fuerzas misteriosas y recargadas con un valor titánico ${ }^{15}$.

A partir de 1816 la causa independentista adquiere un hálito de unión- cooperación entre granadinos y venezolanos, y aparece en escena un fulgurante semidiós, don Simón Bolívar, padre de la independencia, señor y amo de los héroes, delirio de los pueblos, «a quien miraban como una especie de ser sobrehumano, vencedor de imposibles y destinado por el cielo para ser como un segundo redentor ${ }^{16}$. En este momento de la narración Santander también tiene una parte considerable de los rasgos mitológicos, junto a Páez y otros bravos guerreros. «Una de sus mayores glorias - dice Granados- consistió en haber mantenido encendido el fuego sagrado de la libertad en los Llanos Orientales, cuando en el resto del país se había extinguido en 1816» ${ }^{17}$. Como se puede ver, en esta parte del relato es cuando Santander adquiere la investidura de la situación mitológica, ascencional y apolínea, para decirlo en palabras de Durand ${ }^{18}$.

El siguiente paso en la vida militar de Santander es la unión al ejército independiente de Bolívar en 1817-1819 ${ }^{19}$. La vida del Santander militar está expuesta en estos textos como la de un valiente generoso que ayuda a concluir la obra de Bolívar; su encuentro con el Libertador en junio de $1819^{20}$ supuso la unión de un ejército de 2.000 tropas reunidas por Santander en Casanare, bien equipadas, alimentadas, rigurosamente disciplinadas y dispuestas a sacrificar sus vidas por el destino de la patria. Además, supieron ponerle fin a las penurias del hambre y los desafíos del peligro, «hallaron sal para la ración ordinaria de carne y plátanos. Los hombres que conducían a aquellos héroes eran jóvenes que sabían desafiar los peligros y soportar las privaciones y olvidar los cuidados

15 García 157-158, 175-176; Granados 133.

${ }^{16}$ Granados 139; en el mismo sentido, García 139, 168-169; Hno. Justo Ramón 144, 152; Henao y Arrubla 112, 138; Carmel Bernal Pinzón, Historia de Colombia para niños (Bogotá: Ediciones La Idea, 1948): 69; Silvestre del Campo y Ramón González, Historia Patria Ilustrada, Segundo Curso, (Bogotá: Librería Stella, 3a edición, 1950): 85.

${ }_{17}$ Granados 150. A García en esta ocasión no le queda más remedio que reconocer la grandeza de Santander, pero sólo hasta 1818: "A pesar de sus valiosos servicios, sólo surgió a la vida de la inmortalidad y de la gloria, cuando en agosto de 1818, Bolívar le confió la misión de organizar la libertad de Nueva Granada», García 177. También en el mismo sentido de Granados, el texto del Hno. Justo Ramón 145-146. En el caso de Henao y Arrubla, Santander aparece en su relato solamente hasta este año de 1816, como general y jefe de las reducidas tropas rebeldes que huyeron a Casanare, 137.

${ }^{18}$ Ver Supra.

${ }^{19}$ Granados 151; García 178; Henao y Arrubla 139; Hno. Justo Ramón.147; del Campo y González 83.

${ }^{20}$ Es el encuentro previo a la expedición de los Andes, que concluiría con la Batalla de Boyacá en agosto de ese año, batalla decisiva para los independientes y su sucedánea toma de la capital del Virreinato. 
de la vida» ${ }^{21}$. El autor que más énfasis le dio al Santander militar fue Granados: "Su acción militar brilló, pues, en la organización de las tropas mencionadas y en el sistema de guerra que siguió en los Llanos [...], por medio del cual enloqueció a los realistas» ${ }^{22}$. Pero no sólo fue brillante y sagaz, sino también salvador y aureolado.

En este pasaje de la obra militar de Santander están cubiertos muchos de sus caracteres personales y su sello distintivo como hombre de pluma. Se deduce que Santander fue el único capaz de hacer cambiar de opinión al Libertador, que fue escogido entre sus compañeros para llevar la voz unánime de todos, y que tuvo la sagacidad para ofrecer su «vanguardia» para allanar el camino a las restantes tropas. En el fondo de todo está la orientación política de Santander para «mantener la soberanía e independencia de su patria con respecto a Venezuela» ${ }^{23}$. El carácter legalista de un general de brigada, en plena campaña separatista, obedecía más a las condiciones de la guerra, las pasiones y el júbilo apasionado de la victoria y las estrategias políticas tanto de Bolívar como de Santander. El legalismo de Santander se vería claramente materializado después de la victoria de Boyacá, la última guerra en la que participó y coronó de laureles tanto a él como a Bolívar, Anzoátegui, Soublette y los demás oficiales importantes de la campaña. Como veremos más adelante, esta actitud la comprendió al instante Bolívar, al nombrarlo vicepresidente de Cundinamarca.

«Los nombres de Bolívar, Santander y de tantos otros que figuran en la epopeya de la independencia antes y después de Boyacá, vivirán hasta la más remota edad; la gratitud que alienta en los pechos nobles y generosos guardará así mismo la memoria de los héroes ignotos, de esos que también lucharon y cuyas cenizas yacen olvidadas, pero a quienes se consagró un monumento en la capital, en la celebración del Primer Centenario de la Independencia» ${ }^{24}$.

Casi todos los autores de los textos coinciden en que a Santander se le debe «la gloria de haber impreso al Gobierno colombiano un carácter cívico opuesto al militarista que ha predominado en algunas naciones americanas» ${ }^{25}$. Esto implicó una labor administrativa tan tenaz que el Libertador mismo lo llamó el Hombre de la Leyes y el Organizador de la Victoria ${ }^{26}$. Durante sus diversos periodos como mandatario, primero como vicepresidente (1819-1826), luego como primer mandatario (1832-1837) la obra civil de un general pasó por diversos sucesos de gran importancia: reglamentar el ramo de la Hacienda, gestión diplomática para el reconocimiento internacional de Colombia, la regularización de las relaciones entre la Iglesia y el Estado, organizar y promover una

\footnotetext{
${ }^{21}$ Henao y Arrubla 138-139. En el mismo sentido, Granados 152; del Campo y González 83 y ss; Hno. Justo Ramón 149, 151; García 179.

22 Granados 152.

${ }^{23}$ Granados 153.

${ }^{24}$ Henao y Arrubla 148.

${ }^{25}$ Granados 150; también en el mismo sentido García 246; Hno. Justo Ramón 201.

${ }^{26}$ La referencia a Santander como el Hombre de las Leyes, en Henao y Arrubla 191; Granados 177; García 221.
} 
educación laica y liberal, entre otros aspectos ${ }^{27}$. El civilismo de Santander durante este periodo se puede concentrar en una premisa clásica del liberalismo, que David Held distinguió bajo los parámetros de la democracia representativa, «un sistema de gobierno basado en funcionarios electos que se comprometen a representar los intereses o las perspectivas de los ciudadanos dentro de territorios delimitados y a la vez garantizan el imperio de la ley» ${ }^{28}$.

La búsqueda de un equilibrio entre la coerción y la libertad en plena guerra o en situaciones de crisis es lo que puede caracterizar brillantemente a Santander. Y esto lo demostró claramente en el caso de los fusilamientos de 1819, 1824, 1833 y $1834^{29}$. Todos amparados bajo el colchón de la ley. Los autores de estos textos parecen tomar una posición defensiva de la actitud militarista del general en el caso de los fusilamientos de $1819^{30}$. En el caso de los fusilamientos de 1833 y 1834 la actitud de Santander es drásticamente castigada ${ }^{31}$.

Sobre el caso del fusilamiento de Infante, también se siguió un proceso jurídico complejo, confuso y de repente oscuro, hasta el punto que se entró a discutir sobre la competencia de la Alta Corte para ejercer jurisdicción sobre el fuero militar ${ }^{32}$. Este caso mostró la influencia y el poder de Santander sobre el Congreso y sus seguidores y amigos, aunque no siempre. Sobre los fusilamientos de 1833 y 1834 dice el mismo Santander: «El proceso contra los delincuentes se siguió por los trámites legales, concediéndoles todos los recursos necesarios para su defensa» ${ }^{33}$.

No solamente el carácter civilista-militarista de Santander se reflejó en los fusilamientos; también en las facultades extraordinarias del ejecutivo para sobrellevar la guerra y organizar la administración civil. A decir verdad, se trató de un juego de cesiones y contravenciones hechas entre él y el Congreso para ejecutar la administración del Estado. Por esta razón a Santander le tocó resolver la mayor parte de las cuestiones administrativas, embutidas unas tras otras por el legislativo. Pero

${ }^{27}$ García 221-225, 244; Granados 214-215, 267-273; Henao y Arrubla 152-153, 184-186; Hno. Justo Ramón 201203, 275-277; del Campo y González 101-102; Bernal 96.

${ }^{28}$ David Held, La democracia y el orden global. Del estado moderno al gobierno cosmopolita (Barcelona: Ediciones Paidós Ibérica, S.A., 1997) 25.

${ }^{29}$ Sobre los fusilamientos: en 1819, 38 oficiales españoles capturados en la Batalla de Boyacá y un civil español, acusados de conspirar con los bogotanos para reconquistar el poder del rey; 1824, el fusilamiento de Leonardo Infante, coronel venezolano acusado de asesinar al teniente Francisco Perdomo; 1833, 17 conspiradores y el general Mariano París, acusados de rebelión contra su gobierno; 1834, fusilamiento del general español por la misma razón.

${ }^{30}$ Granados 179; García 221.

${ }^{31}$ Henao y Arrubla 184-185; el Hno. Justo Ramón dice que fue lamentable la muerte de París, 276.

32 Granados 218. Este asunto desembocaría en la destitución del presidente de la Alta Corte, el venezolano doctor Miguel Peña, con subrogación de su sueldo durante un año.

${ }^{33}$ Granados 218. 
Santander también fue conciente de las bondades del Artículo 128 de la Constitución y él mismo se abrogaba funciones extraordinarias en ausencia o no de las sesiones ordinarias del Congreso ${ }^{34}$.

Las facultades extraordinarias sirvieron de todos modos para resolver los apremios de la nueva situación y la guerra en el resto del Virreinato y Venezuela, a falta de una legislación nueva y de las múltiples barreras parlamentarias que se suscitaron en la república. Desde asuntos minúsculos como la asignación de sueldos, hasta los referentes a la contribución directa, la organización de la Marina y la milicia nacional, tuvieron que ser resueltos por Santander por medio de las facultades extraordinarias ${ }^{35}$. Santander actuó bajo los parámetros constitucionales para la consecución de recursos en la Guerra del Sur, asunto este que ocasionó ciertos alegatos de Bolívar. Pero en términos generales la llave Bolívar-Santander tuvo frutos positivos en la Independencia de Perú y Bolivia ${ }^{36}$.

Considerado el general en su faceta más liberal, casi todos los textos le reprochan «el haber contribuido en la propagación de perversas doctrinas contenidos en los perniciosos textos de legislación del inglés Jeremías Bentham, y de metafísica del francés Destrut de Tracy -condenados anteriormente por Bolívar y que Santander pretendió que se enseñasen expurgados-» ${ }^{37}$. Además de jacobino, lo catalogaron de materialista grosero, masón e incluso ateo. Sus colaboradores y los más furibundos santanderistas, como Vicente Azuero y Florentino González, lo secundaron en las logias masónicas, la prensa oficial y particular y las tertulias literarias que pregonaron un sentimiento liberal y en cierto modo antidogmático. Estos autores de textos dudan de la sinceridad católica de Santander. Y esta cuestión la vuelven problemática. Las supresiones de conventos, las subrogaciones a los clérigos (v. gr. la edad mínima de 25 años para ser seminarista, la absorción del clero por parte del Estado y los ataques al padre Margallo), son muestras de ello ${ }^{38}$. Pero también $-y$ esto es lo

34 García 221.

35 García 221.

${ }^{36}$ Granados 207; García 211; Hno. Justo Ramón 191, 201.

${ }^{37}$ Granados 269; en el mismo sentido, Hno. Justo Ramón 202, 282; García 221-222; Arboleda Llorente 195.

${ }^{38}$ Estos asuntos en García 224, 246; Granados 269; Hno. Justo Ramón 202, 282; García 221-222; Arboleda Llorente 195.

La cuestión del padre Margallo se refiere al momento en que Santander hizo callarlo en plena celebración eucarística por sus ácidas críticas al sensualismo y utilitarismo de Azuero y los liberales seguidores de Santander. El padre Margallo fundó varios periódicos para defender el catolicismo y fue apresado en 1823 por sus supuestas calumnias al gobierno central.

Valdría la pena también decir que las supresiones y fusiones de conventos, las subrogaciones de sueldos, el número máximo de clérigos residentes en un convento, etc., fueron políticas liberales que también promovió Bolívar, hasta que en 1826 decide colocar de su lado a la Iglesia por los ataques provenientes del ala más radical del liberalismo, es decir, los santanderistas. Bolívar suprime la educación bentahmiana y cierra la logia masónica de Bogotá, apoya decididamente al clero en la restitución de sus haberes y dignidad, y comienza el periplo de su mitologización por parte del Partido Conservador colombiano. Sobre Santander y la Iglesia, ver 
interesante- dudan de su ataque frontal y decidido a la Iglesia Católica, no sin antes recalcar que estos liberales radicales combatieron más bien el fanatismo y la tradición de arraigo católico de la base popular. Como veremos enseguida, la representación de la muerte de Santander es significativamente reveladora.

\section{IMÁGENES LITOGRAFIADAS DEL GENERAL SANTANDER}

La consagración heroica que se hizo de Santander surgió después de su participación en la Batalla de Boyacá: «Santander [...], en el combate de las vanguardias, luchaba contra Jiménez quien, al darse cuenta del desastre de Barreiro, quedó consternado; Santander aprovechó las circunstancias; ordenó una carga impetuosa y simultánea de todas sus tropas y coronó el triunfo» ${ }^{39}$. Como se puede notar, la consagración de la obra heroica se debe, como en el sentido estricto de las situaciones mitológicas lo supone, a la gesta militar. Se es héroe en tanto guerrero. Pero esto es parcialmente cierto en el caso de Santander. El general también es héroe de la administración americana, de la organización civil y militar y de la cultura nacional. Esta fue la obra de un Santander joven, enérgico y vigoroso. Era de «regular estatura; algo corpulento, cabellos lisos y castaños; tez blanca; frente pequeña; ojos pardos con largas pestañas, hundidos, vivos y de mirar penetrante; nariz recta y bien formada; labios delgados y comprimidos, y barba redonda y corta. Estaba dotado de grande energía y resolución» ${ }^{40}$.

En el texto de Henao y Arrubla aparecen dos imágenes litografiadas del general, en dos momentos distintos: la de un general joven en 1819, que viste uniforme de tal, florido y con el cuello cubierto, el cabello parapetado y hacia delante, el bigote estirado y la mirada lánguida; sólo aparece su busto, con los hombros empinados y vistos a medias. Este retrato de Santander es de autoría de Ricardo Acevedo Bernal ${ }^{41}$. Un Santander joven, que aparece en los momentos decisivos de la campaña de Boyacá, posiblemente trata de mostrar la primera etapa de una república naciente, en ciernes, y que está aparejada con el ímpetu de la juventud de uno de sus creadores (ver Imagen 1).

Posteriormente, cuando el relato de estos textos muestra el final de la etapa epopéyica, aparece un Santander viejo, de aspecto patriarcal y vestido de civil. Su cuerpo es enorme, echado en una silla

David Bushnell, El régimen de Santander en la Gran Colombia (Bogotá: El Áncora Editores, 1985) 268-274; sobre Bolívar y su transformación conservadora, la obra más estructural o exhaustiva del personaje, en Gerhard Massur, Bolívar, tomo II (Bogotá: Instituto Colombiano de Cultura): 615.

${ }^{39}$ Granados 166. En el mismo sentido, Henao y Arrubla 144-145; García 182-183; Hno. Justo Ramón 156.

${ }^{40}$ Henao y Arrubla 140.

${ }^{41}$ En Pilar Moreno de Ángel y Horacio Rodríguez Plata, «Santander. Su iconografía» (Bogotá: Editorial Litografía Arco, 1984): 104. En adelante, Iconografía. 
majestuosa y mostrando su espíritu apacible (ver Imagen 2$)^{42}$. En uno de los textos se describe la imagen del Santander maduro:

"Aunque algo obeso, su porte era majestuoso y gallarda la figura; su andar lento, acompasado; los escasos cabellos peinados siempre, trayendo los laterales con gracia y simétricamente hacia las sienes y llevando los anteriores hacia la cima de la cabeza; los bigotes caídos con orden sobre el labio inferior; en las mejillas, abundancia de sangre; los ojos pequeños, grises, vivaces; la nariz recta; los dientes muy blancos y un ligero y constante asomo de sonrisa en las comisuras de los labios delgados y comprimidos» ${ }^{43}$.

Es un Santander maduro y, en algunos casos, viejo, con la mirada refunfuñona y seria, pero paternal, los brazos cruzados, un camisón blanco que sobresale al cuello y el corbatín, saco semiabierto de color negro. Especialmente tratan de reflejar el carácter del hombre de las leyes, quien le dio vida al gobierno y al espíritu de nacionalidad ${ }^{44}$. En los textos también se le concibe como un hombre dotado de energía y resolución, recio $^{45}$, «hecho de frialdad, rigidez y regionalismo, menudos cálculos mercantiles mezquinos para un héroe» ${ }^{46}$. Aquella mirada de «ojillos grises», estirada y poco confiable, que refiriera Fernando González ${ }^{47}$, de un hombre mestizo y ligeramente aindiado ${ }^{48}$, se percata en algunas imágenes de los textos que refieren la semblanza del general Santander (ver Imagen 3).

Por otra parte, existe otra imagen «legalista» del general Santander en los textos. Se trata de una de las más clásicas y conocidas del «Hombre de las Leyes», la estatua que lo muestra con una espada

\footnotetext{
${ }^{42}$ Esta litografía tiene diferentes vertientes. En el caso de Henao y Arrubla y Granados es una versión similar al óleo del pintor mexicano Felipe Santiago Gutiérrez. En el caso de García, es similar a la pintura de autor anónimo del siglo XIX, que reposa en el Museo Nacional. El retrato del Santander civil y viejo que inserta el Hno. Justo Ramón, es la del pintor Acevedo Bernal, en Iconografía 93, 113, 124.

${ }^{43}$ Arboleda Llorente 197.

${ }^{44}$ El retrato del Santander viejo en Granados 268; García 175; Henao y Arrubla 185.

${ }^{45}$ Granados 150; Henao y Arrubla140.

${ }^{46}$ Hno. Justo Ramón 283.

${ }^{47}$ Supra.

${ }^{48}$ Laureano Gómez, El final de la grandeza (Bogotá: Hojas e Ideas, 1993) 31-32. En la biografía más excelsa y mejor elaborada de Santander hay una referencia a un antepasado de Santander de origen indígena; su familia, desde el siglo XVII era más bien andariega, comerciante, en algunos casos odiada y perseguida y sin prestigio social a pesar de su apellido y origen español; esta familia durante el siglo XVIII tenía las condiciones de lo que hoy llamaríamos una clase media con muchos aprietos, con pequeñas propiedades y algunos esclavos en las localidades fronterizas del nororiente del Virreinato granadino. La penuria económica de la familia sólo se vino a solucionar cuando al padre de Santander, Juan Agustín Santander Colmenares, con el auxilio de su cuñado y tutor de Francisco de Paula, Nicolás Omaña, canónigo radicado en Santafé, consigue un puesto en la alta burocracia colonial de San Faustino de los Ríos, en Pilar Moreno de Ángel, Santander. Biografía (Bogotá: Planeta, 1989) 16-17, 28-29.
} 
y la Constitución en mano (ver Imagen 4) ${ }^{49}$. Un crítico de la obra de Costa dijo que la estatua, en términos generales, «traduce perfectamente esta superioridad de la inteligencia y de la energía moral $»^{50}$. Muestra "las líneas del rostro de las ventanillas de la nariz hacia arriba: la frente en especial, el pelo, el peinado, las dimensiones del cráneo, las curvas del ojo, el tamaño de las orejas». Aunque «dicen que la mandíbula de la barba está estrecha, delgada, enjuta; que el general tenía los labios más gruesos, la boca más grande, las mejillas más Ilenas, el bigote siempre cuidado y vuelto un poco hacia las orejas» ${ }^{51}$ : es la imagen del general al regreso de su exilio. Al parecer es una estatua que tomó la imagen de Santander cuando tenía la edad de treinta años (1821), a fin de mostrar a un héroe durante su más gloriosa campaña, «para entregarlo a la inmortalidad» de una manera bella, porque «quizás nada mejor en su género se encuentra por el orbe» ${ }^{52}$. Esta descripción de la estatua hecha por Vezga no nombra en ningún momento los artefactos que acompañan a Santander: la espada y el pliego de la Ley.

La versión del héroe solar «trascendental» que utiliza armas erguidas y alzadas, apuntando hacia arriba, es recurrente en las imágenes de los héroes enseñados ${ }^{53}$; sin embargo, en el caso del general Santander existen algunas imágenes que lo muestran con la espada apuntando hacia abajo, pero con la Constitución encima y sobresaliente, lo que podría sugerir dos cosas: la primera, que el arma no sólo reviste de un carácter espiritual sino intelectual y en este caso más intelectual que espiritual, viril o sexual, como aduciría Durand; y la segunda, que definitivamente Santander no es un verdadero héroe nacional, símbolo del poder y pureza del alma de una sociedad, sino el antihéroe por excelencia, el monstruo que está en lo más profundo de las tinieblas, que presupone una actitud colérica de malignidad y sometimiento a las leyes; al laberinto de las pasiones y enredos, la humillación de la grandeza de Bolívar, héroe de mil batallas y prisionero de la pasión santanderina, quien reconociera que el no habernos compuesto con Santander nos llevara a la ruina.

En la versión mitológica del héroe solar apolíneo, el arma punzante se dirige hacia arriba (v. gr. el caballero luchando contra el dragón). Ahora bien, una espada apuntando hacia abajo o a la Constitución, sin que la punta sobresalga hacia el «cielo» podría darnos algunas pistas para concebir a un Santander efectivamente amo y señor del infierno, por un lado, o por otro, a un Santander

\footnotetext{
${ }^{49}$ Del Campo y González 101-102. En una de ellas aparece la del general Santander con la espada en la mano derecha, apuntando horizontalmente, sobre su abdomen, un pliego con la inscripción «Leyes», que sostiene su mano izquierda y se desborda hacia sus talones, detrás de él. Esta estatua fue construida en 1925 por R. Verlet, y se encuentra en Bucaramanga, en Iconografía 134. Sin embargo, existe una imagen más convencional, en la que Santander tiene la espada en su mano izquierda apuntando hacia abajo y la Constitución extendida en su mano derecha, vestido de magistrado y en actitud solemne, construida por Pedro Costa, en 1878.

${ }^{50}$ Florentino Vezga, «Apreciación de la Estatua», s.f., en Escritos sobre Santander, I 111.

${ }^{51}$ Vezga 111.

${ }^{52}$ Vezga 112.

${ }^{53}$ Durand $152-153$ y ss.
} 
padre e hijo de la nacionalidad, de la nación de los rábulas y espantajo de los dioses solares que encarnaron la figura de los venezolanos, de Bolívar. Sin embargo, en este trabajo existe la tendencia por creer en un Santander pragmático, que entendió las condiciones materiales de su época, acomodado a la rudeza de los campos de batalla y la delicadeza de las minucias legales, personalidad "poco inclinada a especulaciones ideológicas» ${ }^{54}$. Esta imagen de Santander, siguiendo a García Ortiz, muestra que «era lo suficiente militar para hacerse obedecer de militares [...], y hombre de dotes singulares para la administración y el bufete, tales como la requería la formación de una nacionalidad ${ }^{55}$. Más aún: estas imágenes se circunscriben en la lógica de que los grupos de rebeldes criollos que se tomaron el poder en la América Hispana eran ilustres románticos, liberales y de una gran erudición (de la filosofía del derecho, sobre todo). El legalismo de un general de brigada obedecía también a la larga costumbre virreinal de formar abogados y comerciantes con las formas de una educación latinista y eclesiástica: eran, ante todo, civiles y patriotas que se uniformaron con la casaca al calor de la Independencia. A Santander se le comenzó a atribuir la gesta de haber impreso al Gobierno colombiano un carácter cívico, opuesto al militarista, gesta que implicó una labor administrativa tan tenaz que la historia patria le llamó el Hombre de las Leyes y el Organizador de la Victoria (ver más adelante el punto 3).

Existen algunas pinturas "colectivizadas» que muestran al general Santander en el campo de batalla, alrededor de Bolívar y otros oficiales, de la tropa, la llanura, la dificultad del terreno. Entre la más significativa alegoría al óleo en que aparece Santander en los textos, está la de la «Batalla de Boyacá», que reposa en la Quinta Museo de Bolívar de Bogotá (ver Imagen 5) ${ }^{56}$. Esta pintura muestra un campo de batalla repleto, con batallones bien formados en marcha solemne, una caballería en desbandada en medio del sopor y la humareda de la artillería; junto a varias banderas colombianas ondeando, en medio de un completo desorden frente a los batallones de vanguardia, la lucha se percibe de una manera infernal, con estampidas de las tropas españolas desde una loma suavemente empinada. No se sabe a ciencia cierta la posición de Santander. Moreno de Ángel y Rodríguez Plata traen a colación la inscripción y la nota del grabado:

«Batalla de Boyacá [...]. El Ejército realista, disciplinado, aguerrido y bien mandado era dos veces más numeroso. El de los republicanos, fatigados por largas y penosas marchas y desprovisto de todo, menos de valor y constancia, forzó a sus enemigos a admitir una batalla cerca de la ciudad de Tunja. El general Santander, quien mandaba la vanguardia, dirigió las operaciones desde la izquierda [...]».

\footnotetext{
${ }^{54}$ Laureano García Ortiz, «Carácter del general Santander», Estudios Históricos (Instituto Colombiano de Cultura, 1980) 81. Una visión opuesta o negativa del carácter civilista-militarista de Santander, como «una mezcla de militar venezolano y letrado granadino" que explica en gran parte "los errores de su conducta y las contradicciones y las dificultades de la posición ambigua», en Miguel Antonio Caro, Memorias HistóricoPolíticas del General Posada, Ojeada al origen de nuestros partidos políticos (Bogotá: 1882), en Joaquín Posada Gutiérrez, Memorias histórico-políticas, tomo I (Bogotá: Imprenta Nacional, segunda edición de 1929) 262.

${ }^{55}$ García Ortiz 76.

${ }^{56}$ Su autor es Ricardo Moros Urbina, en Iconografía 65. Aparece en García 183.
} 
Es decir, la parte izquierda es la misma donde se ve el tumulto y el encarnizado combate. En el resto del cuadro se ven una casita cercada y una choza de apariencia intrascendentes. El escenario de la guerra está rodeado de una inmensa Ilanura y altibajos montañosos, debajo de un cielo azul grisáceo ${ }^{57}$. Cualquiera que sea la situación, el hecho es que esta alegoría de la «Batalla de Boyacá» es la obra cumbre de la gesta independentista, que enfatiza los esfuerzos, los sufrimientos, la epopeya y el valor heroico. También da colorido a una narración de hechos y batallas casi siempre aburrida por medio de una pintura amplificada, un paisaje estremecedor y el aspecto más sombrío de la naturaleza. Podría ser que desde el punto de vista del romanticismo, el héroe se encuentra ante la situación de buscar armonizar su ser con la versión más radical y salvaje de la naturaleza estilizada, pintada o pensada, alegoría que por lo demás no deja de ser incitante, rebelde y contraria a las disposiciones del destino y los tabúes de la sociedad.

Por último, existe una imagen que concluye con la narración de la epopeya independentista. Precedida por el cuadro de la muerte de Bolívar, el fallecimiento del general Santander se muestra a la manera católica (ver Imagen 6 y 7$)^{58}$. Los autores de los textos enfatizan sobre el auxilio recibido por el arzobispo Mosquera el 6 de mayo de 1840, día de su muerte. Esta tradición de representar católicamente la muerte parece ser heredada de la tradición española fundada por Alfonso $\mathrm{X}^{59}$. La ceremonia de la muerte, siguiendo a Yarza, y los subsiguientes actos sociales, «tienen un carácter ritual y parateatral» con distintas versiones en cada cultura y estamento social.

\footnotetext{
${ }^{57}$ Aparentemente estas alegorías son insignificantes. Sin embargo, en la literatura antisantanderista adquieren un significado preciso. Como se dijo, la brigada de vanguardia era la que se encontraba en el centro del combate y, por tanto, Santander, su comandante, en plena actividad. Estos autores no dejan bien parado a Santander: le atribuyen una cobardía exagerada por haberse escondido en la choza que se encontraba frente al campo de batalla. Basados en algunas conversaciones informales de la época, apuntes de actores que presenciaron los hechos, como O'Leary, el mismo Bolívar, las cartas de Urisarri, en Eladio Urisarri, "Carta Cuarta», Cartas contra Santander. Réplica a las memorias del «Hombre de las Leyes» (Bogotá: Editorial Planeta, 2000): 52; también Guillermo Camacho Montoya, Santander. El hombre y el mito, (Bogotá: Ediciones Revista Colombiana, 1940): 48; Fernando González, Santander (Medellín: Editorial Bedout, 2da. Edición, 1971): 180 y ss. Santander se defendió aduciendo que "Anzoátegui dirigía sus operaciones sin ver las mías, ni yo las de él, porque, como lo habrán notado todos los que conocen el campo de batalla, se ocultan fácilmente los movimientos de una tropa por los matorrales, y la desigualdad del terreno», en sus "Apuntamientos para las memorias sobre Colombia y la Nueva Granada», Memorias del general Santander, prólogo de Eduardo Santa, (Bogotá: Biblioteca Banco Popular, 1973): 58.

${ }^{58}$ Este cuadro en Hno. Justo Ramón 282; Granados 273; García 245. El cuadro que aparece en los textos del Hno. Justo Ramón y Granados es del pintor José María Espinosa, versión en la que no aparecen sus dos sirvientes arrodillados, como sí sucede en el cuadro del texto de García, versión del pintor bogotano Luis García Hevia de 1941, en Iconografía 102. En términos generales ambas pinturas presentan la misma situación de los catorce ciudadanos ilustres junto a un Santander tendido en su lecho de muerte.

${ }^{59}$ Joaquín Yarza Luaces, «Despesas fazen los omnes de muchas guisas en soterrar los muertos», Formas artísticas de lo imaginario, (Barcelona: Anthropos Editorial del hombre, 1987) 260.
} 
En el rito católico es común encontrar una manera algo paradójica de enterrar a los muertos nobles o ilustres. La vestimenta, lo profano, lo mítico y lo mundano rozan muchas veces con las actitudes estrictamente cristianas, su otro mito ${ }^{60}$. De esta manera podemos encontrar un cuadro de la muerte de Santander con un ambiente profano y celestial al tiempo.

Su cadáver aparece rodeado por catorce ciudadanos ilustres pertenecientes al liberalismo más radical y moderado, quienes habían profesado de modo jacobino en sus primeras apariciones publicitarias un enconado odio al fanatismo y la servidumbre del pueblo católico. Sobre su liberalismo y sensualismo anticatólico un autor lo sitúa de forma ambivalente: «pero desgraciadamente restableció las enseñanzas utilitaristas de Bentham y Tracy, de lo cual se arrepintió públicamente años más tarde» ${ }^{61}$.

Acompaña al general Santander el arzobispo Manuel José Mosquera, sentado a su derecha, brazo sobre la cintura, mano suavemente colocada, aprestada a recibir los delicados dedos del general. El arzobispo viste con su traje de jerarquía, cubierto por una gran cruz debajo de su pecho, exactamente al frente de la mano izquierda de Santander. A la izquierda del general aparece sentado su doctor de cabecera, médico José Félix Merizalde. Viste elegante. Su rostro refleja un pesar profundo, mientras apoya su mano derecha sobre el hombro del general. Al frente del médico se encuentran los dos sirvientes de Santander, Rufino Camacho y Ana Josefa Ontiveros Omaña. Ambos están arrodillados, pero revelan dos miradas diferentes; el primero tiene su mirada enjuta, languidecida, y la ama de llaves despreocupada y afable.

Al fondo, rodeando al prócer, se encuentran Antonio Obando, Rafael Mendoza, Francisco Soto, Patricio Armero, Vicente Azuero, Ignacio Quevedo, Florentino González, Francisco Antonio Durán, Francisco Oberto, Bonifacio Espinosa, Pablo Pontón y Antonio María Silva. Los asistentes están finamente vestidos, con paños estirados, chalecos, corbatines y con una apostura digna. Algunos de ellos aparecen suspirando y sollozando, pero dejando la impresión de que era mejor que descansara en paz.

El aspecto de Santander es lánguido, esquelético. Está vestido con pijama blanca y gorro. Yace tendido medio inclinado sobre una almohada que le sostiene espalda y cabeza. Su aspecto exterior degradado era producto de la enfermedad del hígado que le hizo perecer ${ }^{62}$. En la habitación que yace Santander se pueden palpar una camarilla cubierta por encima con telares finos que bordean los cuatro ángulos del tendido, cortinas semiabiertas y soportadas por barrotes de madera. Existe un ambiente lúgubre, pero suavemente iluminado. En el fondo del cuadro alcanza a percibirse un cuadro con algunos jinetes, al parecer de alguna batalla o adelantamiento en los Llanos.

\footnotetext{
60 Yarza 271.

${ }^{61}$ Arboleda Llorente 195.

${ }^{62}$ Algunas referencias al cadáver del general Santander, en Antonio Martínez Zulaica, Cólicos republicanos. Patobiografía del general Santander, (Tunja: Universidad Pedagógica y Tecnológica de Colombia, 1978) $182-183$.
} 
El cuadro de su muerte refleja la situación del santanderismo y a su primigenio autor en una actitud perentoria, es decir, la referencia a la metáfora familiar del padre rodeado de sus hijos en el último momento, que seguirán su obra sin desvarío alguno o por caminos diferentes, pero atendiendo a su memoria. En fin, este cuadro muestra la decrepitud de una trayectoria y una época, de un personaje que al final de la narración, justo antes de su muerte, apareció sirviendo «algunos cargos modestos y el de representante al Congreso» ${ }^{63}$, en el que fue violentamente ultrajado por algunos furiosos antisantanderistas.

\section{IMAGEN 1.}

\section{FRANCISCO DE PAULA SANTANDER. ATRIBUIDO A RICARDO ACEVEDO BERNAL}

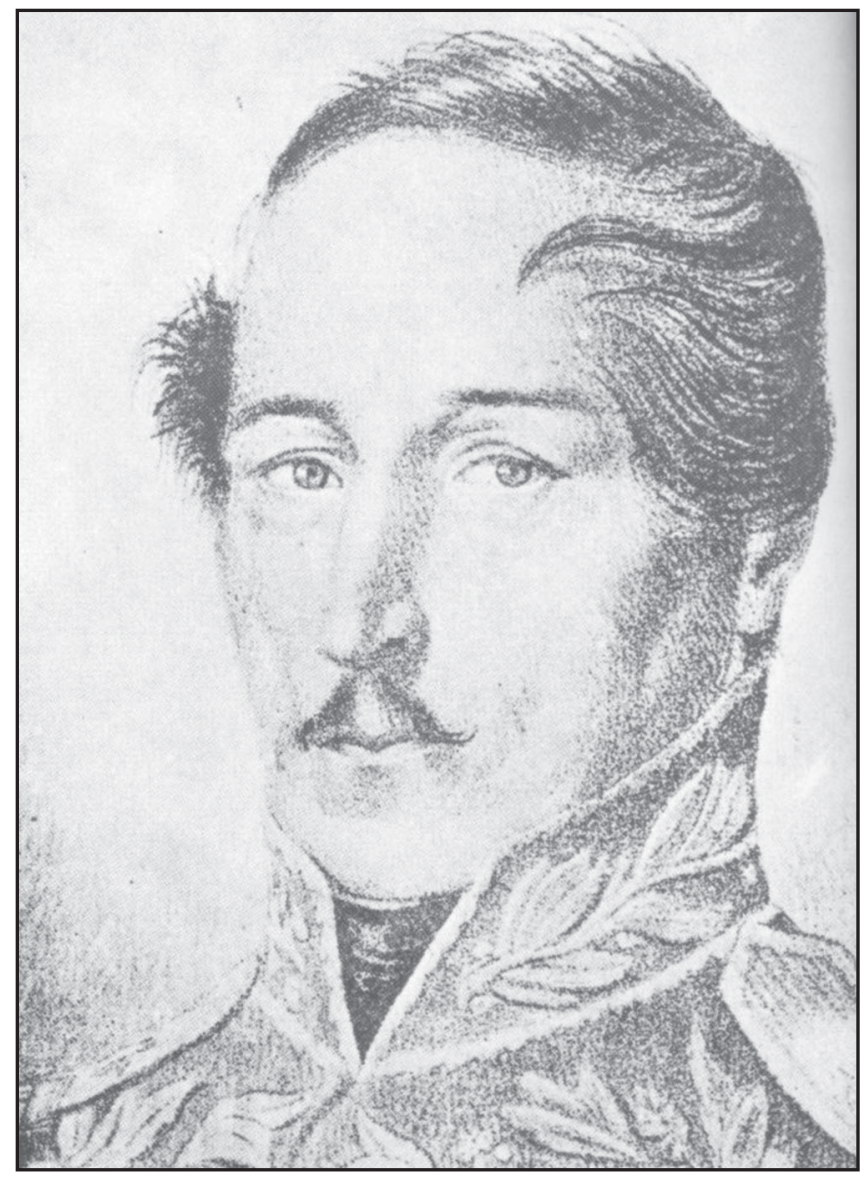

${ }^{63}$ Hno. Justo Ramón 281. Casi todos los héroes de la epopeya independentista tienen "cuadros» similares al final de sus vidas, incluyendo el propio Libertador, que muere en Santa Marta después de un largo viaje, de desencuentros, contrariedades, rechazos, incomprendido y casi arruinado. 
IMAGEN 2.

FRANCISCO DE PAULA SANTANDER. EL HOMBRE DE LAS LEYES. ÓLEO POR EL PINTOR MEXICANO FELIPE SANTIAGO GUTIÉRREZ

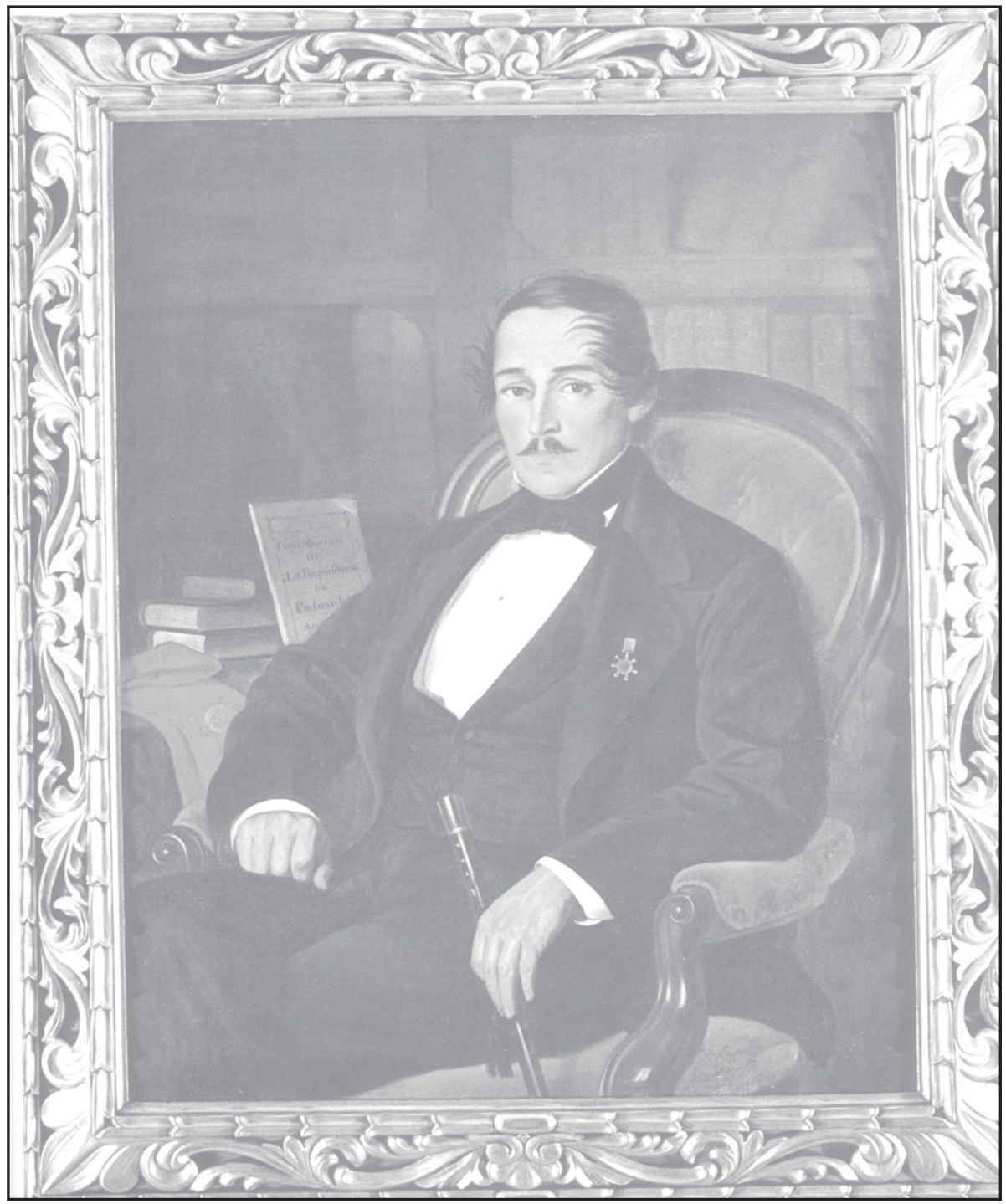


IMAGEN 3.

ÓLEO CON LA LEYENDA «FRANCISCO DE P. SANTANDER. RESOLUCIÓN DE LA CÁMARA DE REPRESENTANTES DE LA NOCHE DEL 6 DE MAYO DE 1840. COSTEADO POR LOS DIPUTADOS FLORENTINO GONZÁLEZ, ANTONIO HERRÁN Y POR EL CIUDADANO HIGINIO CUBILLOS»

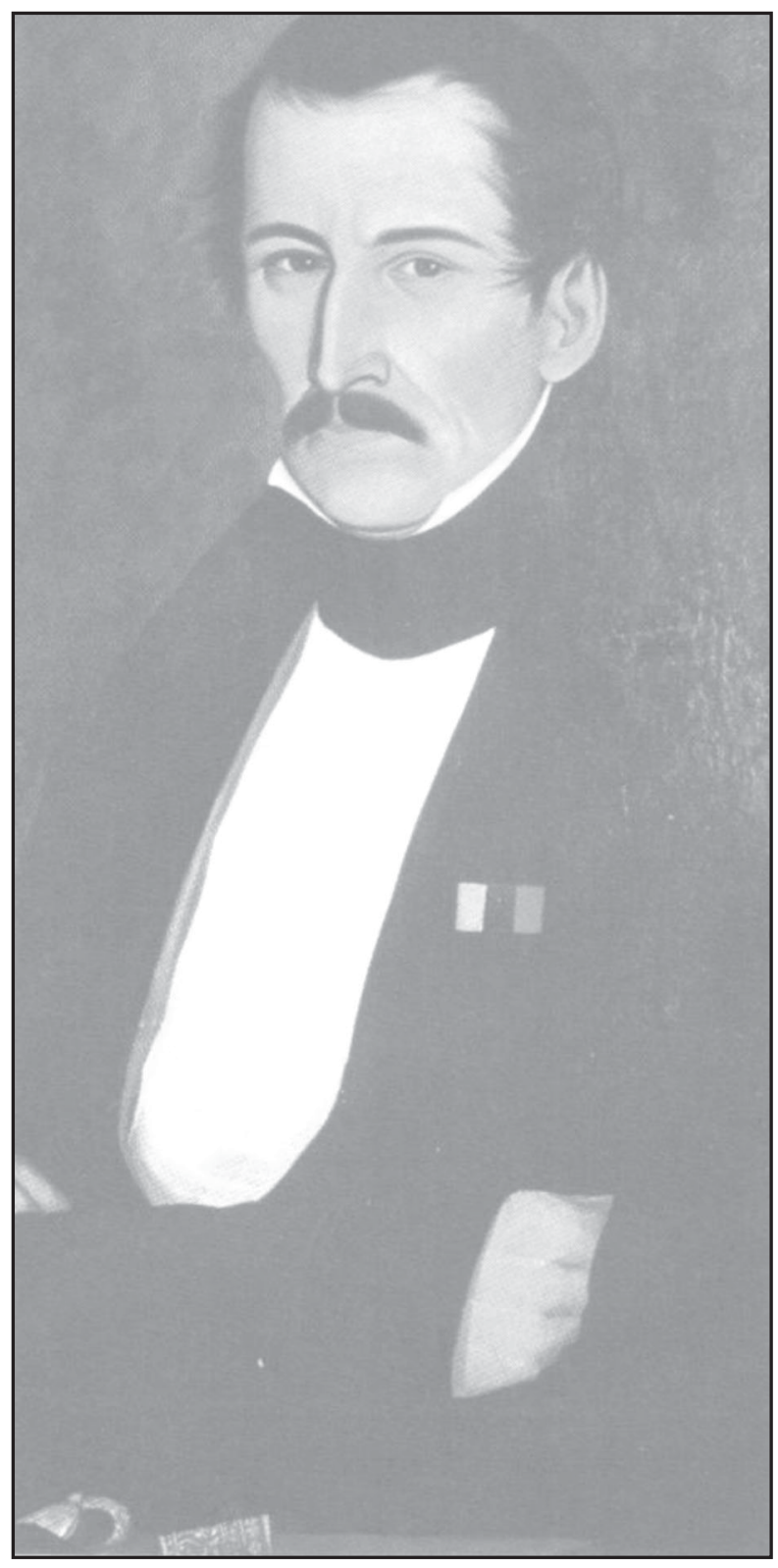


IMAGEN 4.

ESTATUA DE SANTANDER. OBRA DEL ESCULTOR FRANCÉS R. VERLET

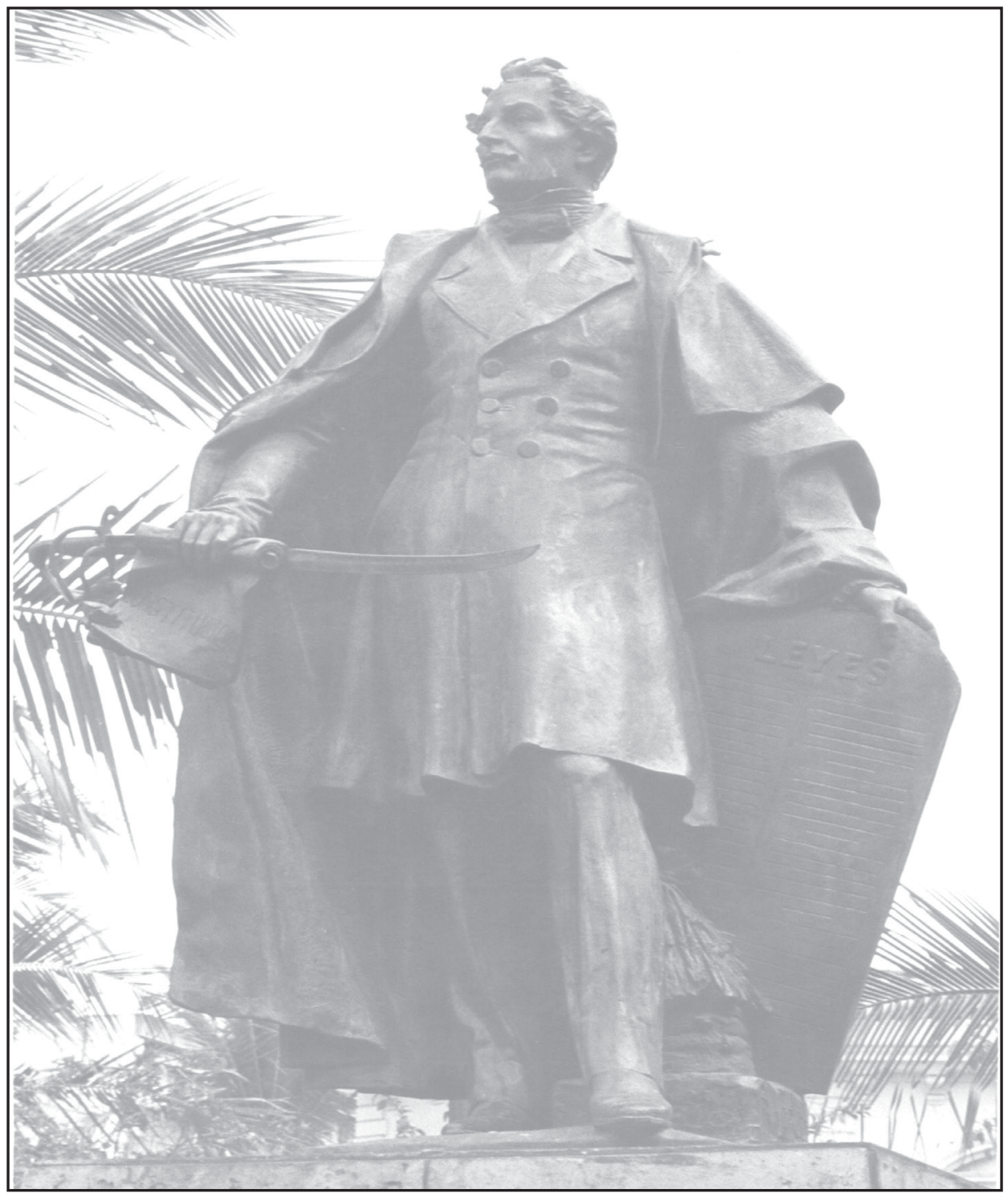


IMAGEN 5.

BATALLA DE BOYACÁ

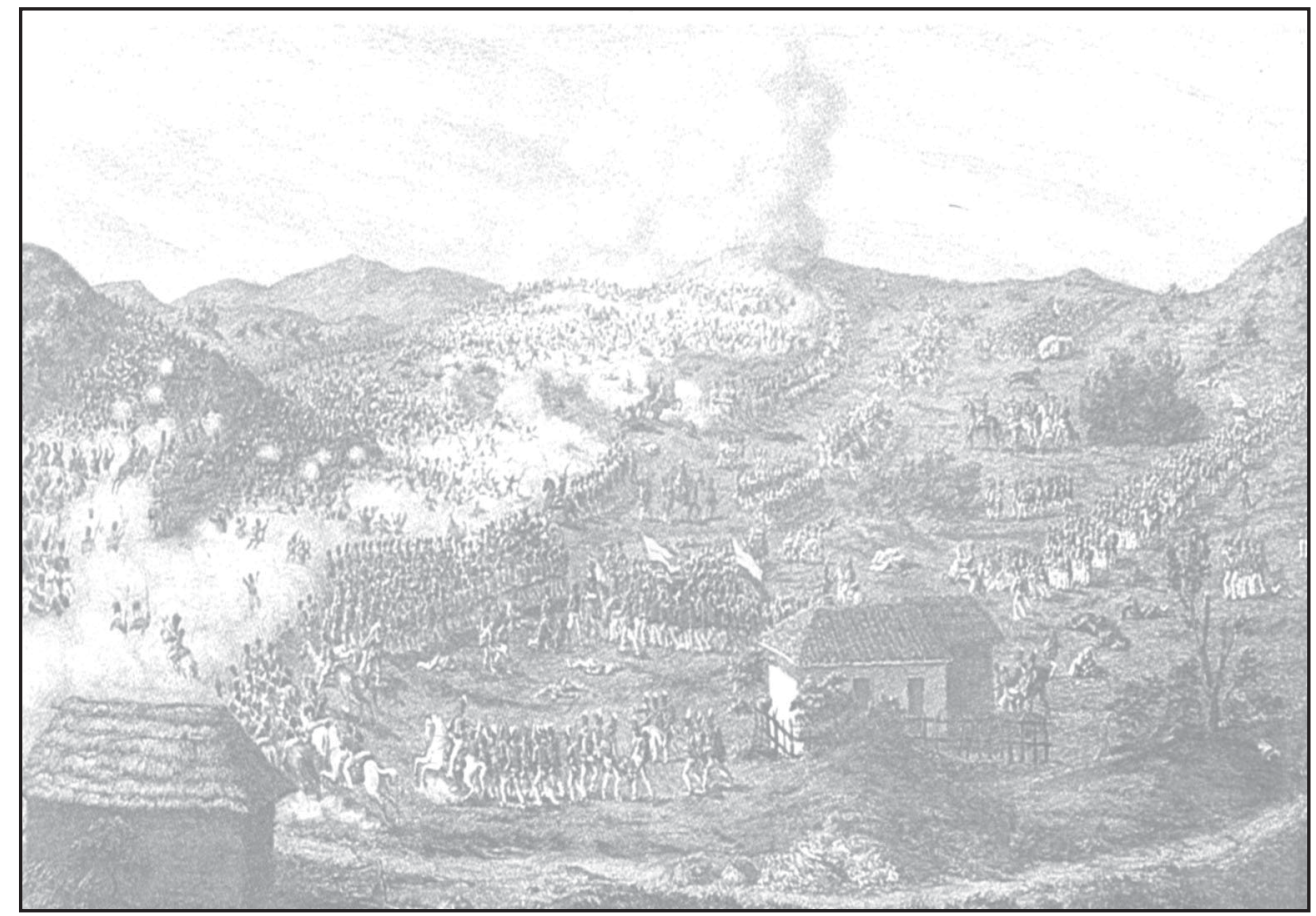

IMAGEN 6.

FALLECIMIENTO DEL GENERAL SANTANDER. CUADRO DE JOSÉ MARÍA ESPINOSA

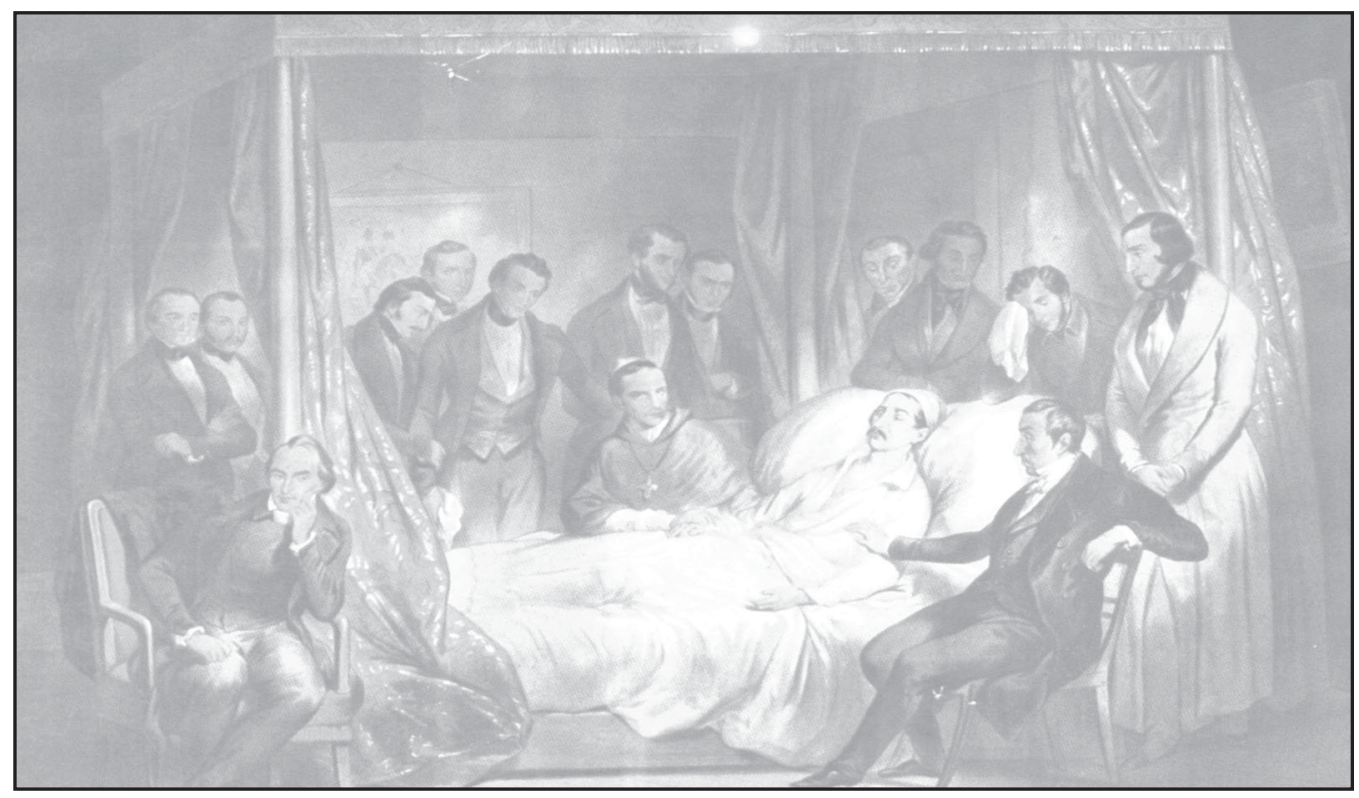


IMAGEN 7.

MUERTE DEL GENERAL SANTANDER. CUADRO DE LUIS GARCÍA HEVIA

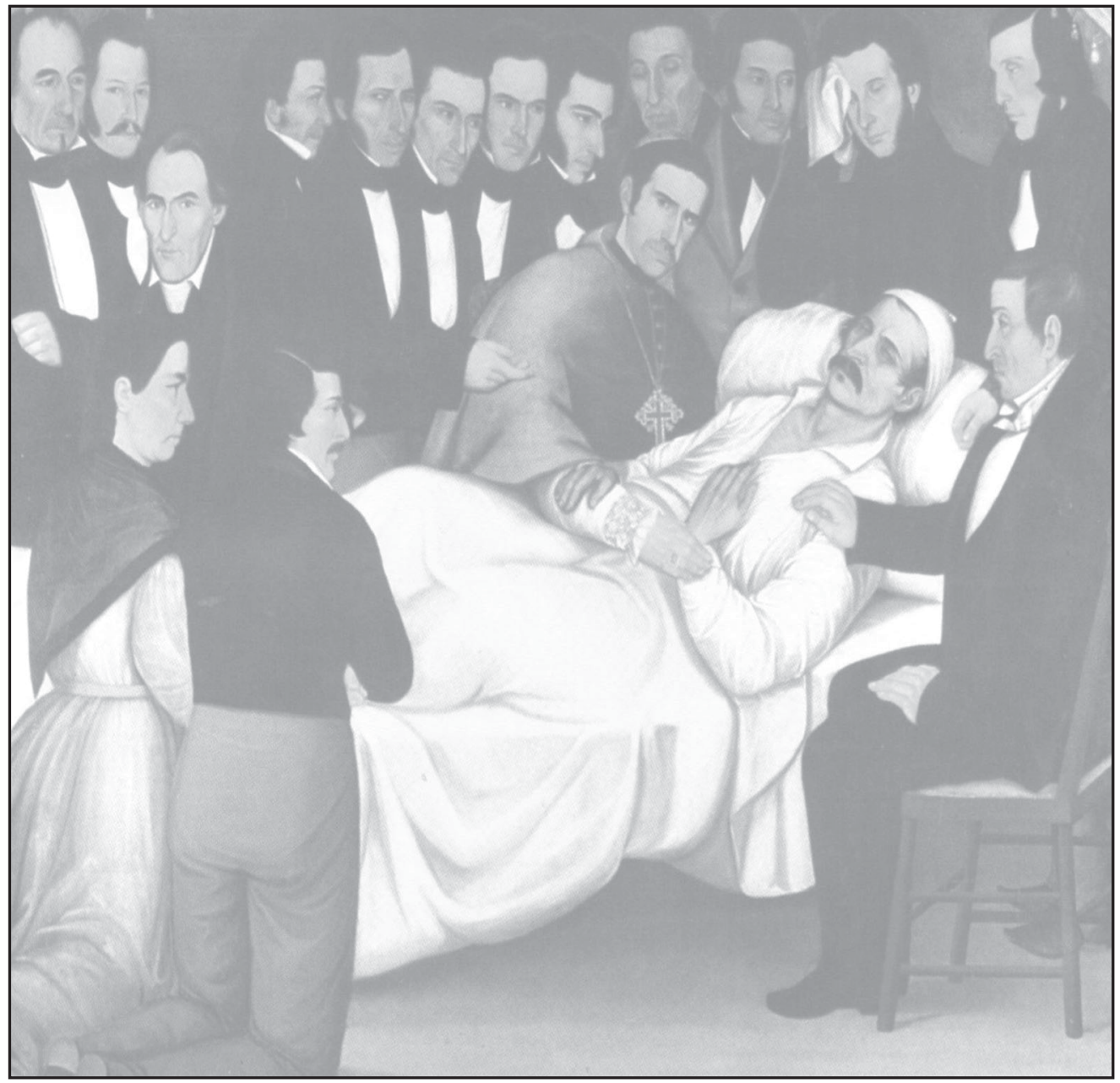

\section{ENEMISTAD CON BOLÍVAR Y ORIGEN DEL SANTANDERISMO. LA CONVENCIÓN DE OCAÑA. CONSPIRACIÓN DE SEPTIEMBRE DE 1828. SANTANDER PADRE DE LA NACIÓN.}

Un verdadero antihéroe es quien se enfrenta a otros héroes de su misma condición y temporalidad. Después de sus enemistades «ilustres» con Nariño y Páez, aún existe un momento más álgido en la vida, obra y trayectoria del Santander antiheroico ${ }^{64}$. Se trata de su enemistad con el Libertador Simón Bolívar, el Zeus del panteón de la mitología procera y padre de la patria:

\footnotetext{
${ }^{64}$ La oposición santanderista a Nariño y su federalismo se trasladaron a la tribuna pública y la prensa; pero más deplorable es presentada la muerte de Nariño, como un sino trágico de pesadumbres arrastrada por la indiferencia y el odio. El prócer murió en Leiva en 1823, "achacoso, casi ciego y en una extremada pobreza»,
} 
"A pesar de la buena armonía que reinó durante varios años entre Bolívar y Santander [...], es evidente que los dos representaban temperamentos y tendencias distintos: Bolívar, el de los venezolanos, militares valientes, en los que predominaba la índole del hombre de los Llanos, para quienes los méritos de la espada alcanzan a sobreponerse a las leyes. Santander, el granadino, hombre civil y serrano, de los que pensaban que 'si las armas nos dieron independencia, sólo las leyes no darán libertad'»65.

El origen de esta enemistad se sitúa en las Ilamadas Actas de dictadura, configuradas por la Constitución boliviana, las supuestas arbitrariedades cometidas por Santander y sus más cercanos amigos, las actas de Guayaquil y Quito, que supusieron el clamor fervoroso del pueblo hacia Bolívar, la rebelión de Páez y la exclusión paulatina del poder que sufrió el vicepresidente apenas asumió Bolívar el mandato. En cierto punto de la narración se encubre al Libertador diciendo que él «estaba convencido que para salvar la nación de la anarquía no había otro remedio que aceptar la dictadura que se le ofreció» ${ }^{66}$.

Sin embargo, Bolívar no contaba con el repentino poder y el influjo que se había abrogado Santander durante poco más de 7 años de ejercer el poder. Tampoco contó con que los santanderistas quedarían «profundamente» heridos por el decreto de enero de 1827 que otorgó a los rebeldes de Caracas total amnistía ${ }^{67}$. Más aún, el Libertador se envistió completamente, desde su llegada de Perú, de las facultades extraordinarias y expidió decreto tras decreto para aliviar la situación económica del país «y perfeccionar la administración de justicia» ${ }^{68}$. Además de las actas de Guayaquil y Quito, de las intrigas de los bolivarianos y las encarnizadas conjeturas que se propalaron contra Santander, el Libertador comenzó a desplazar lentamente del poder al general granadino, hasta que por medio de un decreto de agosto de 1828 lo excluyera completamente del poder. Como era de esperarse, insisten los autores de los textos, "la reacción legalista colombiana contra el militarismo de Páez», la Constitución boliviana, los agitados debates de prensa, las rebeliones del Ejército colombiano en el Perú, festejadas por Santander, darían pie para el nacimiento de los partidos políticos en Colombia $^{69}$. Antes:

después de su vindicación personal en el Congreso y su retiro a la vida eterna de manera triunfal. Estos textos entreveran la maldad de sus enemigos «santanderistas» y su culpabilidad en una muerte tan penosa. En el caso Páez, resumido en su disposición antigranadina y militarista, como causante de la disolución colombiana, Santander sale mejor librado. Véase García 223, 228; Granados 213-214, 217-218; Hno. Justo Ramón 204-207.

${ }^{65}$ García 110.

${ }^{66}$ García 229.

${ }^{67}$ Granados 221.

${ }^{68}$ Hno. Justo Ramón 209-210; Granados 221.

${ }^{69}$ Granados 222-223; García 256; Hno. Justo Ramón 215. En algunos casos Santander es absuelto del dudoso manejo que se hace al empréstito de 1824, en Granados 214. 
«Bolívar había llegado al apogeo de su gloria. El conde Delaly, que estaba en relaciones con los gobiernos de Madrid, Rusia y Prusia, le propuso desde Londres que se coronara como monarca. Iguales propuestas le hacían desde Venezuela Páez y Pando; Gamarra y sus amigos le insinuaban lo mismo en Lima. Bolívar, sin dar contestación, remitió los pliegos a Santander para que los presentase al Congreso porque sólo quería vivir como ciudadano y morir libre» ${ }^{70}$.

Este pasaje muestra que tanto Bolívar como Santander eran «opuestos a las ideas monárquicas». Además, queda circunscrita la idea de que Bolívar se dejó influenciar por personajes que lo adularon y se aprovecharon de su gloria para emprender la ruta de la dictadura republicana. A Santander le tocó el lado más flaco de la dictadura bolivariana y del "veneno de los chismes». Estos textos muestran una visión de las desavenencias entre Santander y Bolívar que se aproxima a una lucha titánica entre dos superhombres, dominada por las pasiones y las enemistades, las diferentes posturas personales y los proyectos que lideraban cada uno de estos:

«Desde el año de 1826 se hicieron ostensibles las desavenencias entre Bolívar y Santander; ellas fueron ahondándose paulatinamente hasta el punto de verse al fin separados los dos próceres por una enemistad profunda.

«En la formación de la enemistad influyeron veneno de chismes, propinado por los aduladores de uno y otro para enemistarlos, malas inteligencias entre los dos insignes hombres e imprudencias de ambos» ${ }^{71}$.

Uno de los autores despliega su estatuto bolivariano:

"Hoy la crítica ilustrada y serena no admite que hayan sido ambiciones de mando del Libertador los móviles de este al instituir la Presidencia vitalicia, sino una verdadera necesidad social y política para Bolivia y otros países» ${ }^{72}$.

Las divisiones entre Bolívar y Santander «se ahondaron luego en el Congreso de 1827 y en la Convención de Ocaña. El hecho de haber suprimido Bolívar la vicepresidencia cuando asumió la dictadura acabó de amargar el ánimo de Santander» ${ }^{73}$. La Convención de Ocaña, según Granados, fue un verdadero maremagno de «arterías e intrigas» inducidas por los santanderistas, que al final de cuentas no supo ni modificar la Constitución ni calmar los ánimos ${ }^{74}$. Mas durante varias sesiones (2 de marzo a 11 de junio de 1828) se pudo palpar que los aspectos críticos de la Constitución de 1821 terminarían siendo un detonante peligroso para el futuro de la Gran Colombia y su creador:

\footnotetext{
${ }^{70}$ García 226; Hno. Justo Ramón 207.

${ }^{71}$ Granados 222. En la misma línea, Hno. Justo Ramón 209.

72 Hno. Justo Ramón 209.

${ }^{73}$ Granados 224.

${ }^{74}$ Granados 227-229.
} 
la conspiración de muerte contra Bolívar y la disolución de la unión republicana. Entre los aspectos más debatidos están las limitantes de las facultades extraordinarias, los proyectos federalista y centralista, el régimen de las municipalidades, entre otros ${ }^{75}$.

En los textos se habla de un «ambiente caldeado en que se forcejeaba la nación» para conservar la esperanza de la unidad y el restablecimiento de la paz. Pero ese mismo «ambiente caldeado» entre liberales y serviles terminó por Ilevar a la ruina definitiva la obra de los libertadores. Santander y Bolívar no salen bien librados de la Convención de Ocaña: el partido de los «secuaces de Santander, federalista por principio o por oportunismo», propugnó el debilitamiento del poder ejecutivo. El legalismo de Santander salió a relucir en su faceta más negativa, cuando se hizo elegir diputado de la Convención por su partido: «Triunfó por buena mayoría este bando [el santanderista], y entre sus diputados pudo sacar a Santander: la ley de convocatoria presentada para su firma lo excluía, pero él la hizo modificar por el legislador en el sentido de que solo el Presidente en ejercicio no pudiera ser elegido» ${ }^{76}$. A Bolívar lo calificaron de ser un excesivo centralista y partidario de un poder ejecutivo «robusto». Tanto Santander como Bolívar fueron catalogados de ser los atizadores de la discordia, «vana esperanza, porque las aspiraciones de los dos partidos eran irreconciliables y estaban atizadas por odios personales» ${ }^{77}$.

El balance de la Convención resultó en un estrepitoso fracaso: el abandono de la Convención por parte de los bolivarianos ${ }^{78}$. Era de esperarse que la motivación de este partido por abandonar la Convención fuera atizada por las «pasiones», las discordias y las actitudes misteriosas de los personajes; los episodios críticos en la conformación de la nacionalidad, en este caso, hacían "gravísimo daño» a la reputación de Bolívar, Santander y la República, y de manera irreducible «ya en Colombia andaban encendidas las pasiones en torno a la constitución de Cúcuta, a la rebelión de Páez, al gobierno del Vicepresidente y, por lo mismo, a las posibles actitudes de Bolívar a su regreso del país, y los sondeos en referencia vinieron a constituir un nuevo pábulo lanzado a la hoguera de la discordia» ${ }^{79}$.

En 1828 la trama de acontecimientos suscitados entre bolivarianos y santanderistas no dejó más remedio al Libertador que asumir la dictadura absoluta, hecho catalogado como un error político ${ }^{80}$. Este error, dicen los autores, concibió «el horrible proyecto de asesinar al Padre de la Patria» ${ }^{81}$. En

\footnotetext{
${ }^{75}$ Granados 228; García 229; Hno. Justo Ramón 216.

76 Hno. Justo Ramón 215.

77 Hno. Justo Ramón 215.

78 Hno. Justo Ramón 216.

${ }^{79}$ Hno. Justo Ramón 209.

${ }^{80}$ Granado 231; Hno. Justo Ramón 217.

${ }^{81}$ Hno. Justo Ramón 217
} 
los textos también aparece el general Santander como director, consejero o auxiliador del plan, pero en todos se reitera que no se le probó culpabilidad alguna. Mas su pena de destierro y la conmutación de la muerte, dejan el espacio abierto para cualquier tipo de especulación ${ }^{82}$. Ahora, queda por resolverse el drama impuesto por la narración heroica: ¿quién sería capaz de atentar contra la vida del eximio héroe?, ¿fue justa la pena impuesta a Santander por un crimen que no cometió? Entre los que tomaron parte del plan contamos con figuras jóvenes, radicales, personajes misteriosos, de tierras lejanas, revolucionarios, en fin, gente inicua ${ }^{83}$. Con estos antecedentes no sería difícil culpar al general Santander como el principal instigador de los jóvenes de la Sociedad Filológica, a más poetas románticos pertenecientes a una generación de autodidactas líricos e impetuosos ${ }^{84}$.

En los textos el Libertador es presentado como un gran hombre, generoso y paternal por conmutarle la pena de muerte a Santander ${ }^{85}$. Queda la sensación también que la pena de destierro impuesta a Santander deja como gran vencedor de la lucha de titanes a este. Mientras tanto, los dos años de gobierno que le restan a Bolívar se consuman en dolorosas penas, enfermedades, agotamiento, una guerra con Perú, las desavenencias con Páez, que se muestra más reticente que nunca con el Libertador, las insurrecciones de Córdoba, Obando y López, y el abandono de la Gran Colombia a la suerte de la guerra civil ${ }^{86}$. Pero el ascencionismo se refriega una vez más cuando el general regresa de su exilio en 1832 y se consagra como el padre fundador de la nacionalidad y la república, el que la salvó nuevamente de las tinieblas. Elegido presidente de la República de la Nueva Granada, se demuestra «históricamente el arraigo que en Colombia tiene el horror a la dictadura y a los gobiernos personalistas» ${ }^{87}$.

El virtual triunfo de Santander sobre la dictadura de Bolívar y el militarismo que encarnaban este y los venezolanos, como la «dictadura» de Urdaneta, se puede percibir en el proyecto de construir una nación moderna en medio de las tradiciones heredadas de la Colonia (el clientelismo o el paternalismo, la toga y la espada, por citar algunos ejemplos), favorables a la ruta santanderina. Más allá de que estos autores exponen la trayectoria y obra de un Santander real, es evidente que su narración se adapta a un fin, una profunda manifestación de la mitologización de las situaciones:

\footnotetext{
82 García 230; Granados 233; Hno. Justo Ramón 219; del Campo y González 102; Bernal 88 ; Henao y Arrubla 171.

${ }^{83}$ Granados 233; el Hno. Justo Ramón refiere así a los dos extranjeros que participaron en el hecho: «dos individuos de nacionalidad francesa y de oscuros antecedentes: Juan Francisco Arganil y Agustín Horment», 218.

${ }^{84}$ Granados 231. La Sociedad Filológica se estrenó en Bogotá en 1828 y concurrían a ella jóvenes literatos como Luis Vargas Tejada. En el fondo tuvo carácter de secreta y fue sitio de reuniones clandestinas de los conspiradores que atentaron contra Bolívar.

85 Granados 234.

${ }^{86}$ Granados 234, 240, 244, 252-255, 267; García 231-233, 243-244; Hno. Justo Ramón $234,275$.

${ }^{87}$ Arboleda Llorente 195. En el mismo sentido, Granados 273.
} 
«Santander es considerado como fundador del sentido político granadino bajo el aspecto de que no obstante haber sido hombre de espada, él imprimió al Gobierno colombiano un carácter genuinamente legalista y cívico [...]; a él pues, debe reconocérsele el mérito de haber señalado la estela que han seguido comúnmente nuestros mandatarios, algunos de los cuales, inspirados por un profundo sentimiento cívico, han sido estrictos cumplidores de la ley y fieles servidores de la causa democrática rectamente entendida» ${ }^{88}$.

\section{CONCLUSIÓNES}

En los textos existen muchos elementos que se aproximan a la realidad y otros que se asemejan más a una situación mítica, pero todos eran conscientes -o conocedores- de los debates historiográficos, filosóficos y políticos que rodeaban la obra de Santander. En cualquier caso, la idea era encubrir a los dos héroes de los yerros y defectos individuales y justificar sus actuaciones, incluso si tocaba inculpar a otros hombres o circunstancias.

También en los manuales de historia patria la identidad nacional aparece como el resultado de unos significantes que son refrendados por la religión, el territorio, las normas morales y civiles, la iconografía patriótica, entre otros. La narración y las imágenes de estos textos están circunscritas en un contexto nacionalista, de tipo conciliatorio entre las elites partidistas. De las desavenencias legadas por las guerras civiles, el medio siglo XX fue un periodo de modernización, industrialización y nacionalismo, y Santander, por qué no, encarnaba la idea de un héroe que reunía al mismo tiempo el liberalismo y la tradición. En los textos se describe la idea de la unidad nacional como un cuerpo de ideas del «ser o deber ser del colombiano", mediante los mitos fundacionales de la nacionalidad, patriotas, batallas, efemérides y símbolos.

El arte y las imágenes litografiadas, además, aparecen en los manuales de historia patria a fin de que el cuerpo de ideas e imágenes del «ser o deber ser del colombiano», a través de la enseñanza de la historia, contribuya a la formación del ideal nacionalista «reivindicativo» de los mitos fundacionales de la nacionalidad. La imagen nos permite pensar, leer o imaginar las categorías específicas de la identidad nacional inmersa en los textos. ¿Cómo mostrar la idea de la unidad nacional a través de estas imágenes? Son varios los factores que pueden dar luces al respecto. En el arte nacionalista-romántico se testimonian hechos particularmente sugerentes, especialmente con la obra del género retratista de José María Espinosa. En este género se plasma un contenido social que hace visible un pasado lejano.

La imagen dibujada de Santander es usualmente la de un general con constitución en mano y espada en carea, que refuerza la percepción de una identidad civilista-guerrera como la ilusión de

${ }^{88}$ Granados 273. 
un pueblo durante su ascenso como entidad libre. Siguiendo a Burke, se puede recalcar que «lo que recogen los retratos no es tanto la realidad social cuanto las ilusiones sociales, no tanto la vida corriente cuanto una representación social de ella» ${ }^{89}$. En estos retratos se descubren cuidadosamente los ambientes naturales y modelos sociales que hacen parte de la cultura material y espiritual de la época ${ }^{90}$. Un ambiente independentista se abre paso para concebir un nuevo orden de cosas, una nueva vida y un mundo mejor. La naturaleza y el hombre se funden; la individualidad del ser contrasta con la bondad de la naturaleza, o dicho en términos de Burke, el arte y la política se compenetran como la realización inconciente de un programa histórico ${ }^{91}$. Al general Santander lo rodea un espacio amplio, donde la naturaleza se entremezcla con fenómenos heroicos contundentes: cruce de ríos y montañas, desenlaces de una turbulencia casi insospechada, animales que dominan los Llanos y los Andes, tropas desvencijadas, multitudes y personajes rebeldes dominados por la fuerza y el genio del héroe, en fin. Pero también existen imágenes donde el general Santander aparece como personaje central, en pintura individualizada, que compite con las formas de la pintura colectivizada. Mas en ambos casos el héroe y la naturaleza ocupan un lugar prioritario, sea su naturaleza individual, su esencia (espada y constitución), sea el ambiente que lo rodea, la naturaleza en su aspecto más prolijo.

Por otra parte, el análisis del cuerpo, la vestimenta, posturas y gestos permitieron revelar los mensajes superpuestos a la imagen del héroe. Desde el punto de vista de la historia del arte, «las poses y los gestos de los modelos [...] siguen un esquema y a menudo están cargados de un significado simbólico. En este sentido el retrato es una forma simbólica» ${ }^{92}$. El cuerpo representa una imagen

\begin{abstract}
${ }^{89}$ Peter Burke, Visto y no visto. El uso de la imagen como documento histórico (Barcelona: Editorial Crítica, 2001): 31-32; también de Beatriz González, José María Espinosa Abanderado del arte en el siglo XIX (Bogotá: Banco de la República, El Áncora Editores, 1998).

En términos generales, nos dice González, quien llama a la obra de Espinosa «iconografía procera», el retrato reemplazó a la pintura religiosa y mantuvo un lugar de preeminencia que se mantuvo hasta mediados del siglo XIX. Aunque hubo retratistas en la época colonial, como Pedro José Figueroa, fue Espinosa «el primer pintor colombiano que se salió de los moldes de la pintura colonial: trabajó sin el mecenazgo de la Iglesia, sin modelos establecidos, no pintó asuntos religiosos [...]», 58.
\end{abstract}

Sin embargo, como vimos en el punto 3, en este estudio no sólo se recurrió al género retratista como la principal aportación a la imagen litografiada de los textos; también los óleos, grabados y fotografías de estatuas y cuadros realizados por diversos autores, además de Espinosa, como Acevedo Bernal, Carrillo Cervantes, del escultor italiano Pedro Costa, autor de la primera estatua de Santander en 1878, y Luis García Hevia, uno de los pintores de la muerte de Santander; estas dos últimas imágenes son las que más aparecen en los textos.

${ }^{90}$ Burke 101-128.

${ }^{91}$ Burke, La fabricación de Luis XIV (Madrid: Editorial Nerea, 1995) 18.

${ }^{92}$ Burke, Visto y no visto... 30. Sobre el cuerpo también se puede confrontar de Jacques Le Goff, Roger Chartier y Jacques Revel (dirs.), La Nueva Historia, (Bilbao: Ediciones Mensajero, 1988) 111-114. 
estética y cultural del gran hombre, en relación con su genio, alma y esencia, su trayectoria y obra, representados en diversos materiales visuales y narrados. También el cuerpo es la representación física del héroe, que lo hace un ser real, de carne y hueso; aspectos suyos durante la juventud, la vejez y la muerte, su rostro y gestualidades, contextura y «accesorios» (el bigote, por ejemplo), plasman la evolución de una tendencia histórica que corre aparejada con la existencia del héroe ${ }^{93}$.

El mito de Santander, esa incesante historia rodeada de héroes y antihéroes, se plasma en los textos a través de un cuerpo de ideas e imágenes que fueron creados con un sentido tendencioso, deliberado: la superación de los yerros y defectos de la nacionalidad. Pero más que una sentencia oficiosa por parte de sus autores, está aquí en juego el imaginario de una colectividad que visibilizó un pasado para darle sentido común a la identidad de todo un pueblo.

\section{BIBLIOGRAFÍA}

- $\quad$ ARBOledA lLORENTE, José María, Historia de Colombia, Enseñanza Secundaria y Primaria Superior, (FTD, colección Champagnat, 1939).

- $\quad$ BERNAL PINZÓN, Carmel, Historia de Colombia para niños (Bogotá: Ediciones La Idea, 1948).

- $\quad$ BURKE, Peter, Visto y no visto. El uso de la imagen como documento histórico (Barcelona: Editorial Crítica, 2001).

- _- La fabricación de Luis XIV (Madrid: Editorial Nerea, 1995).

- CAILLOIS, Roger, «El mito y el hombre», traducción de Ricardo Baeza, Ediciones Sur, Buenos Aires, 1939

- $\quad$ CAMACHO MONTOYA, Guillermo, Santander. El hombre y el mito, (Bogotá: Ediciones Revista Colombiana, 1940).

- $\quad$ CARO, Miguel Antonio, «Memorias Histórico-Políticas del General Posada, Ojeada al origen de nuestros partidos políticos» (1882), en Joaquín Posada Gutiérrez, Memorias históricopolíticas, tomo I (Bogotá: Imprenta Nacional, segunda edición de 1929).

- CORREA, Ramón, «Bocetos Biográficos», Boletín de Historia y Antigüedades, VI 61 (julio de 1909).

- DEL CAMPO Silvestre y Ramón González, Historia Patria Ilustrada, Segundo Curso, (Bogotá: Librería Stella, $3^{a}$ edición, 1950).

\footnotetext{
${ }^{93}$ En las situaciones míticas de estos textos escolares, el cuerpo del héroe se aproxima a la versión apolínea de Gilbert Durand, que fue referida en la Introducción de este artículo. Según este autor, el cuerpo y los accesorios que los acompañan, como las flechas, las espadas o cualquier otro objeto o arma, son simbolismos diairéticos entendidos como una palabra, cosa o noción que encierra otro significado mental, sentimental. En este caso, cree Durand, el significado encerrado es el de la sexualidad o virilidad del héroe, que también trae a colación las diferentes nociones de poder en una cultura o narración mítica.
} 
- DURAND, Gilbert, Las estructuras antropológicas de lo imaginario. Introducción a la arquetipología general, (Madrid:Taurus, 1981).

- «Enseñanza de la Historia Patria. Normas, estímulos, sanciones» (Bogotá: Ministerio de Educación Nacional, 1949).

- $\quad$ GADAMER, Hans-Georg, Mito y razón (Barcelona: Ediciones Paidós Ibérica, 1997).

- GARCíA, Julio César, Curso Superior de Historia de Colombia, de conformidad con los programas oficiales vigentes sobre la materia para cuarto año de enseñanza media, 4to año (Bogotá: Editorial Voluntad, 1971, 10ª edición).

- GARCÍA ORTIZ, Laureano, "Carácter del general Santander», Estudios Históricos (Instituto Colombiano de Cultura, 1980).

- $\quad$ GHOTME, Rafat, «Santanderismo, antisantaderismo y la Academia Colombiana de Historia: la operación histórica en el proceso de construcción de nación en Colombia, 1910-1970», Anuario Colombiano de Historia Social y de la Cultura, 34 (2007).

- GÓMEZ, Laureano, El final de la grandeza (Bogotá: Hojas e Ideas, 1993).

- GONZÁLEZ, Beatriz, José María Espinosa. Abanderado del arte en el siglo XIX (Bogotá: Banco de la República, El Áncora Editores, 1998).

- GONZÁLEZ, Fernando, Santander (Medellín: Editorial Bedout, 2da. Edición, 1971).

- $\quad$ GRANADOS, Rafael, Historia de Colombia La Independencia y la República, adoptado al programa oficial de sexto año, tercera edición, (Medellín: Bedout, 1959).

- HELD, David, La democracia y el orden global. Del estado moderno al gobierno cosmopolita (Barcelona: Ediciones Paidós Ibérica, S.A., 1997).

- $\quad$ HENAO, Jesús María y Gerardo Arrubla, Compendio de la Historia de Colombia; para la enseñanza en las Escuelas Primarias de la República, (Bogotá: Librería colombiana Camacho Roldán \& Cía., 1930, 13ª edición).

- $\quad$ HOBSBAWM, Eric, Los ecos de la marsellesa (Barcelona: Editorial Crítica, 1992).

- $\quad$ IBÁÑEZ, Pedro María, «Informe anual del Secretario de la Academia», Boletín de Historia y Antigüedades, VI.65 (octubre de 1910).

- «Información del Secretario sobre la Cátedra de Historia», Boletín de Historia y Antigüedades, XXXVI (1949).

- $\quad$ "Informes Anuales de los Secretarios de la Academia, 1902-1952», compiladas por Roberto Velandia, Academia Colombiana de Historia, Bogotá, 1952

- $\quad$ LE GOFF, Jacques, Roger Chartier y Jacques Revel (dirs.), La Nueva Historia, (Bilbao: Ediciones Mensajero, 1988). 
- MARTíNEZ ZULAICA, Antonio, Cólicos republicanos. Patobiografía del general Santander, (Tunja: Universidad Pedagógica y Tecnológica de Colombia, 1978).

- MORENO DE ÁNGEL, Pilar y Horacio Rodríguez Plata, Santander. Su iconografía (Bogotá: Editorial Litografía Arco, 1984).

- MORENO DE ÁNGEL, Pilar, Santander. Biografía (Bogotá: Planeta, 1989).

- POSADA GUTIÉRREZ, Joaquín, Memorias histórico-políticas, tomo I (Bogotá: Imprenta Nacional, segunda edición de 1929).

- RAMÓN, Justo, S. C., Historia de Colombia. Significado de la obra colonial. Independencia y República (Bogotá: Librería Stella, Sexta Edición Revisada, 1954).

- $\quad$ RIVAS RAIMUNDO, «Duda Histórica», Boletín de Historia y Antigüedades, VI.64 (septiembre de 1910).

- $\quad$ SANTANDER, Francisco de Paula, «Apuntamientos para las memorias sobre Colombia y la Nueva Granada», Memorias del general Santander, prólogo de Eduardo Santa, (Bogotá: Biblioteca Banco Popular, 1973).

- URISARRI, Eladio, Cartas contra Santander. Réplica a las memorias del «Hombre de las Leyes» (Bogotá: Editorial Planeta, 2000).

- VEZGA, Florentino, "Apreciación de la Estatua», s.f., en Escritos sobre Santander (Bogotá: Fundación para la conmemoración del bicentenario, 1988).

- $\quad$ YARZA LUACES, Joaquín, «Despesas fazen los omnes de muchas guisas en soterrar los muertos», Formas artísticas de lo imaginario, (Barcelona: Anthropos Editorial del hombre, 1987). 